\title{
Matching Renewable Energy Systems to Village-Level Energy Needs
}

John H. Ashworth

Jean $W$. Neuendorffer
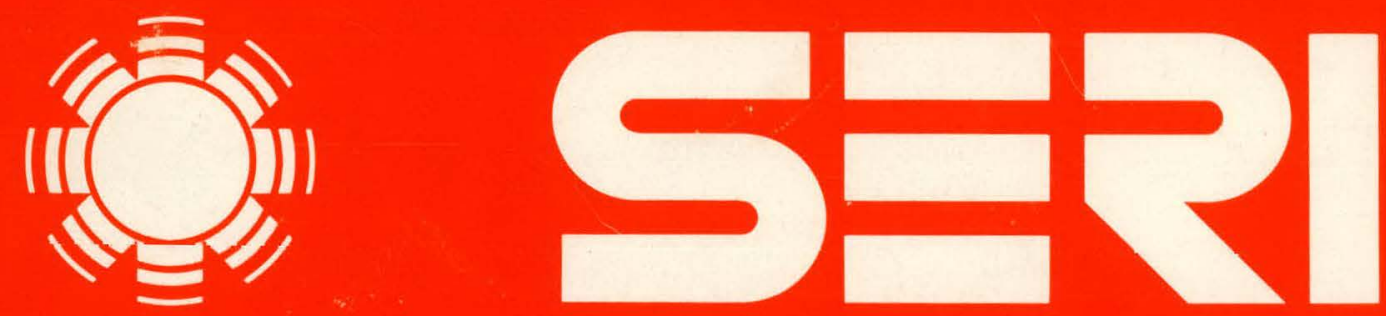

Solar Energy Research Institute A Division of Midwest Research Institute

1617 Cole Boulevard

Golden, Colorado 80401

Operated for the

U.S. Department of Energy

under Contract No. EG-77-C-01-4042 


\section{DISCLAIMER}

This report was prepared as an account of work sponsored by an agency of the United States Government. Neither the United States Government nor any agency Thereof, nor any of their employees, makes any warranty, express or implied, or assumes any legal liability or responsibility for the accuracy, completeness, or usefulness of any information, apparatus, product, or process disclosed, or represents that its use would not infringe privately owned rights. Reference herein to any specific commercial product, process, or service by trade name, trademark, manufacturer, or otherwise does not necessarily constitute or imply its endorsement, recommendation, or favoring by the United States Government or any agency thereof. The views and opinions of authors expressed herein do not necessarily state or reflect those of the United States Government or any agency thereof. 


\section{DISCLAIMER}

Portions of this document may be illegible in electronic image products. Images are produced from the best available original document. 
Printed in the United States of America Available from:

National Technical Information Service

U.S. Department of Commerce

5285 Port Royal Road

Springfield, VA 22161

Price:

Microfiche $\$ 3.00$

Printed Copy $\$ 5.25$

\begin{abstract}
NOTICE
This report was prepared as an account of work sponsored by the United States Government. Neither the United States nor the United States Department of Energy, nor any of their employees, nor any of their contractors, subcontractors, or their employees, makes any warranty, express or implied, or assumes any legal liability or responsibility for the accuracy, completeness or usefulness of any information, apparatus, product or process disclosed, or represents that its use would not infringe privately owned rights.
\end{abstract}


SERI/TR-744-514

UC CATEGORY: UC $-58 \mathrm{e}$

MATCHING RENEWABLE ENERGY SYSTEMS

TO VILLAGE-LEVEL ENERGY NEEDS

JOHN H. ASHWORTH

JEAN W. NEUENDORFFER

JUNE 1980

MASTER

PREPARED UNDER TASK NO. 4326.05

\section{Solar Energy Research Institute}

A Division of Midwest Research Institute

1617 Cole Boulevard

Golden, Colorado 80401

Prepared for the

U.S. Department of Energy

Contract No. EG-77-C-01-4042

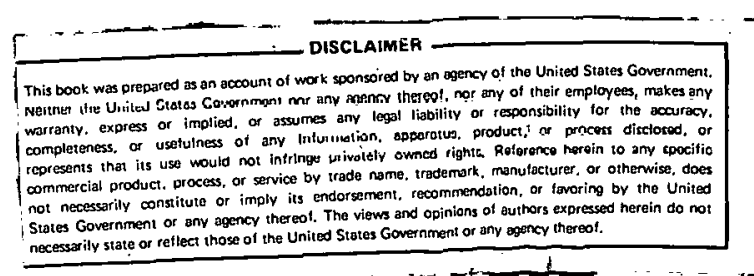




\section{THIS PAGE \\ WAS INTENTIONALLY \\ LEFT BLANK}




\section{PREFACE}

This report was prepared by the International and Remote Applications Groups of the Community and Consumer Branch of the Solar Energy Research Institute (SERI). It is the second in a planned series of Developing Country Policy studies designed to provide information, analytic support, and policy guidance to the International Division of SERI and to decision makers in the U.S. Department of Energy and other U.S. government agencies. The objective of this paper is to provide a new analytic tool for systematically matching the characteristics of energy needs in developing country sites with those of available renewable energy technologies. After the matching process is explained, examples of matching technologies for four energy end uses are given to illustrate the process. Recommendations for field-testing and refining this procedure are developed, as are observations on needed research and development, technology modification, demonstration, and commercial production for each of the four illustrative end-use energy needs.

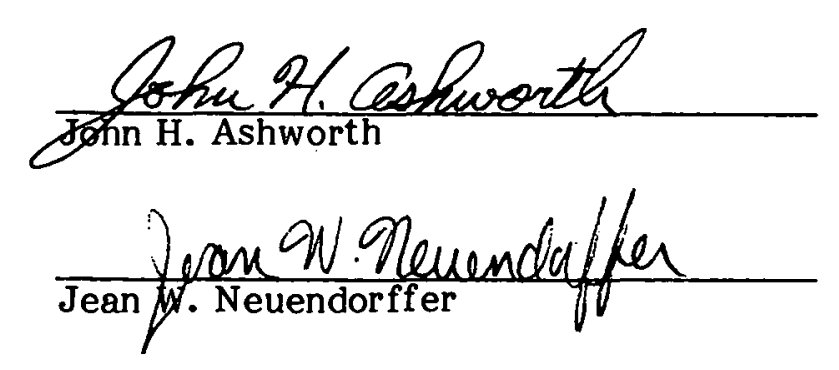

Approved for:

SOLAR ENERGY RESEARCH INSTITUTE

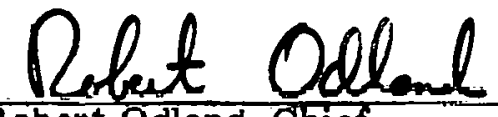

Robert Odland, Chief

Community and Consymer-Branch
Pon M. Veigel, Manage
Planning Applications and Impacts Division 
THIS PAGE

WAS INTENTIONALLY

LEFT BLANK 


\section{ACKNOWLEDGEMENTS}

This paper has benefited greatly from the comments and additions from several readers. Inside SERI, Richard Meunier, John Kadyszewski, and Ronal Larson provided detailed suggestions that improved the conceptual framework, the organization, and the research and development recommendations. Lalit Sen of the Rural Electrification Corporation of India and Thomas Graham of Donovan, Hamester, and Rattien, Inc., provided extensive comments that helped sharpen the analysis. Many participants in the SERI/USAID Workshop on Evaluation Systems for Renewable Energy Technologies held on 20-22 February 1980 gave valuable suggestions. In particular, Willem Floor, George Burrill, Jeff rey Dellimore, Alan Roth, and Irene Tinker contributed significantly to the refinement of the methodology. Finally, we would like to thank David Brunel for his extensive research assistance. 
THIS PAGE

WAS INTENTIONALLY

LEFT BLANK 


\section{SUMMARY}

\section{OBJECTIVE}

This report provides an analytic framework for the identification and development of renewable energy projects in developing countries. It is directed toward development planners, international financial organizations, and foreign assistance agencies who are interested in the potential rural development of small-scale, decentralized renewable energy sources as alternatives to fossil fuel and electrical generation.

\section{DISCUSSION}

Despite the expanded funding of renewable energy projects by foreign assistance and developing country organizations, project planning and analysis normally have been restricted to either technological field testing or engineering feasibility studies. What has been needed is a more comprehensive method of identifying and developing renewable energy projects that will best serve the most urgent rural energy needs. This report attempts to provide such a thorough planning process.

This process offers to development planners and donor agencies a set of characterization tools that, when applied to the energy needs in a particular location, will be readily compatible with information on the output of available energy systems. By collecting data on the specific characteristics of energy needs and technologies, the project planner can match energy needs with the most appropriate technology. The matching process is based on two fundamental premises: (1) that the choice of an energy technology should proceed from a careful identification of the final users' basic human needs and their characteristics; and (2) the match between the characteristics of each energy need and the output of each energy option should be as perfect as possible within the constraints imposed by cost and maintainability. The concern is not only with the identification of systems that can provide the required amount of energy, but also with the factors that determine whether a particular technology will be adopted and supported by the local user.

The report outlines the five-step matching process, briefly explains what information is needed to complete each stage, and shows how each phase will help a project planner choose the best energy technology. To further illustrate the matching process, seven basic human needs for energy are selected along with seven potential renewable energy technologies. Twelve criteria are developed to characterize each need as well as each energy system. Because no individual site or group has been identified, this illustration of need/technology matching only outlines the process using characteristics common to many developing country sites.

\section{CONCLUSIONS}

From matching the characteristics of technologies and needs, technology options are identified along with some observations on additional research and development needed to increase the quality of the matching between each need and one or more technology options. 
After illustrating the process, the report summarizes the advantages and difficulties presented by the needs/technology matching process. Emphasis is on how such a process can be integrated into existing development programs and how the results of the various steps can be integrated into the project identification process and into the hardware adaptation programs of energy research institutions and equipment manufacturers. Because the matching process is only theoretical and general, the method should be fieldtested and subsequently modified to be usable by local-level development planners. 


\section{TABLE OF CONTENTS}

1.0 Introduction $\ldots \ldots \ldots \ldots \ldots \ldots \ldots \ldots \ldots \ldots \ldots \ldots \ldots \ldots \ldots \ldots \ldots \ldots \ldots$

2.0 A Process for Matching Energy Needs with Renewable

Energy Technologies................................. 5

2.1 Central Assumptions Underlying the Process ................. 5

2.1.1 Basic Human Needs Approach...................... 5

2.1.2 The Necessity of Matching Characteristics of

Needs and Technologies .......................... 6

2.2 Steps in the Needs/Technology Matching Process ............... 7

2.2.1 Step One: Choice of Program Goals ................... 7

2.2.2 Step Two: Identification of Energy Needs ................ 9

2.2.3 Step Three: The Preliminary Screening of Technologies ......... 9

2.2.4 Step Four: Matching Technologies with the Needs

and Resource Base of Each Site .................... 10

2.2.5 Step Five: Technology Choice and Installation ............. 12

2.3 Abbreviating the Technology Selection Process ................. 12

3.0 A General nlustration of the Matching Process .................. 15

3.1 Identification of Basic Needs for Energy ................... 16

3.2 Renewable Energy Technology Alternatives .................. 16

3.3 Development of Characterization Criteria $\ldots \ldots \ldots \ldots \ldots \ldots \ldots \ldots \ldots \ldots 17$

4.0 Observations, Recommendations, and Conclusions $\ldots \ldots \ldots \ldots \ldots \ldots \ldots \ldots \ldots$

4.1 Results of the Illustrative Matching Process $\ldots \ldots \ldots \ldots \ldots \ldots \ldots \ldots \ldots \ldots 21$

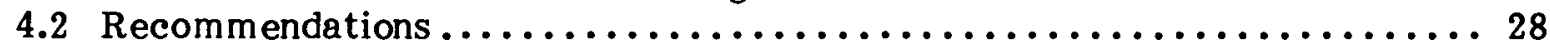

4.2.1 Application of the Matching Process to

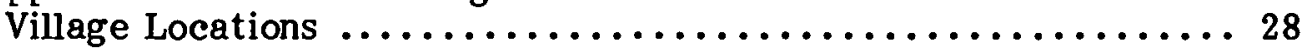

4.2.2 Survey on Cost Components of the Matching Process........... 29

4.2.3 Improving the Needs/Technology Fit .................. 29

4.2.3.1 Basic Research and Development ............... 30

4.2.3.2 Applied Research/Technology Modification ............ 30

4.2.3.3 Demonstrations of Potentially Useful Systems......... 31

4.2.3.4 Commercialization Efforts .................. 32

4.3 Conclusions on the Usefulness of the Matching Process $\ldots \ldots \ldots \ldots \ldots \ldots 32$

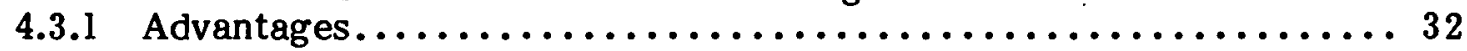

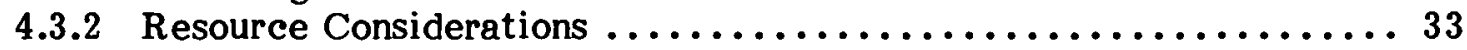

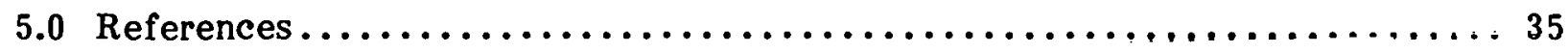

Appendix A: Matching Basic Needs with Renewable Energy Technologies ......... 37

Appendix B: Current Research on Needs and Technologies . . . . . . . . . . . . 49 


\section{THIS PAGE}

WAS INTENTIONALLY

LEFT BLANK 


\section{LST OF FIGURES}

Page

2-1 Needs/Technology Matching Process $\ldots \ldots \ldots \ldots \ldots \ldots \ldots \ldots \ldots \ldots \ldots$

\section{LST OF TABLES}

3-1 Basic Needs for Energy $\ldots \ldots \ldots \ldots \ldots \ldots \ldots \ldots \ldots \ldots \ldots \ldots \ldots \ldots \ldots \ldots \ldots$

3-2 Renewable Energy Technologies and Their Output $\ldots \ldots \ldots \ldots \ldots \ldots \ldots \ldots$

3-3 Characterization Criteria $\ldots \ldots \ldots \ldots \ldots \ldots \ldots \ldots \ldots \ldots \ldots \ldots \ldots \ldots \ldots \ldots \ldots$ 


\section{SECTION 1.0}

\section{INTRODUCTION}

In the past six years, the cost and availability of energy supplies have become main factors in determining the direction and pace of economic and social development in the non-OPEC nations of the Third World. Spiraling costs of importing fossil fuels and constructing the distribution systems for centralized electrical generation, along with increased restrictions placed on nuclear power systems, have led development planners, international financial organizations, and foreign assistance agencies of industrial nations to examine the potential of small-scale, decentralized, renewable energy sources for meeting both immediate and long-range rural energy needs. A recent Solar Energy Research Institute (SERI) report (Ashworth 1979) found that over $\$ 225$ million currently is committed by foreign assistance organizations to the development, installation, field testing, adaptation, and manufacture of renewable energy systems in developing countries. In addition, many Third World nations have committed substantial amounts of their own internal development funds to promote these new indigenous sources of energy (Gall 1978; Ravenholt 1978).

Most of this activity in renewable energy systems has been undertaken on a project-byproject basis. Project planning and subsequent analysis normally has been restricted to either field-testing a particular renewable energy system in one or more developing country or engineering a feasibility study of one proposed system to meet the particular energy needs of a single site. An overall analytic framework is missing within which such field testing or specific feasibility studies can be conducted.

This report is a preliminary effort to provide that analytic context for the identification and development of specific projects and has four major objectives:

- to provide development planners and donor agencies with characterization tools that when applied to the energy needs in a particular location will be readily compatible with information on the output of available energy systems;

- to provide current renewable energy technology alternatives for meeting a given rural energy need in a developing world setting;

- to identify basic and applied research, field testing, and adaptation that may be required to improve the match between certain energy technologies and the characteristics of a particular rural need for energy; and

- to identify areas where more information must be collected on the characteristics of either energy needs or technologies to facilitate the choice of an appropriate technology.

Specifically, this report provides a process for matching energy needs with available energy technologies.* The process is built on two fundamental assertions, which are discussed at greater length in Sec. 2.1:

*Field projects that promote energy conservation through increased efficiency are also needed. Except for the recommended research and development in biomass combustion discussed in Sec. 4.0, this report focuses on projects that use new energy sources rather than those that increase efficiency in fossil and traditional fuel use. 
- the choice of an energy technology (or of any technology) must proceed from a careful identification of the final user's basic energy needs and their characteristics; and

- the match between the characteristics of each energy need and output of each energy option should be as perfect as possible within the constraints imposed by the social and physical environment, the cost of the systems, and the ability of local residents to keep the energy systems in satisfactory operating condition.

Built around the presentation of a process model, this paper does not serve as a comprehensive handbook to instruct program managers on what technologies to select for a particular project. Rather, such selections are the result of the process described here, with the solution being unique for each location and each energy user. The report presents potential technology options based on a limited number of important requirements for each basic need. Before an appropriate match between energy systems and needs can be made for a specific location, a careful survey of the local energy needs should be performed, the characteristics of these needs determined, and the needs ranked in order of priority by the villagers or local planning officials.

The concern here is not only with identifying systems that technically can provide the required amount of energy but also with the social, organizational, and cultural factors that determine whether a particular technology will be adopted and supported by the local user. Throughout this paper, emphasis is placed on involving the final village energy consumer in each step of the matching process. Although initially more costly and time consuming, such active participation speeds the process of technology introduction and adaptation, as well as facilitates maintenance and training activities. This method needs to be tested in several Third World locations to determine if (1) all of the criteria important for need characterization and technology selection have been included or if (2) certain criteria could be eliminated without affecting the matching process. Only through such field tests can this process be proven as a general procedure that would apply to rural development projects in a wide variety of locations. Field testing also will modify and simplify the approach so it can be easily used by local community leaders as well as project planners.

Section 2.0 outlines a proposed five-step matching process, explaining briefly what information is needed to complete each stage and how each phase will help the project planner in the choice of energy technology. The presentation closes by discussing the pressures to abbreviate the technology selection process and the problems that may be generated by neglecting one or more steps.

Section 3.0 illustrates the needs/technology matching process. Seven basic human energy needs are selected along with seven potential renewable energy technologies. Twelve criteria are developed that characterize each need as well as each energy system.

The authors drew upon published reports detailing energy demand in rural developing country settings, energy resource availability, and the performance of specific renewable energy technologies.* Because no individual site or group of energy users has been identified, this illustration of need/technology matching only outlines the process in general terms, using a range of characteristics common to many rural developing country sites.

*For a discussion of available literature, see Appendix B. 
When applied to a particular location, this process ensures the acquisition and interpretation of basic information such as local availability of energy resources (insolation, wind regime, supply of flowing surface water, etc.), local energy need characteristics, and detailed engineering cost estimates. The data on local energy resources are particularly important for renewable energy systems, since their output varies according to local weather and environmental conditions.

Cost information for renewable energy systems has been included mainly to illustrate its position as a key criterion in the matching process and to indicate the enormous range of costs possible within a given technology. The cost of delivered energy is determined by a wide range of conditions including the sizing of the system, the amount of storage included, the transformation of energy from one form to another, and the characteristics of the local energy demand pattern. As energy system manufacturers and development planners have repeatedly emphasized, the cost of energy output can be determined only on a site-by-site analysis.

Section 4.0 summarizes the advantages and difficulties presented by the needs/technology matching process. Emphasis is on how the results of the various steps can be integrated into the project identification process and the hardware adaptation programs of energy research institutions and equipment manufacturers.

To illustrate further the actual mechanics of the matching process, the authors conducted an initial matching of five illustrative basic needs (cooking, crop drying/food preservation, food processing, refrigeration, and provision of potable water) with those renewable energy technologies that appear to have a good potential "fit" with each need, based on the initial screening performed in Step Three of the proposed matching process. The findings of each matching are presented in Appendix A and are summarized in the first portion of Sec. 4.0. A set of technology options is identified for each need, along with some observations on additional research and development needed to increase the quality of the matching between each need and one or more technology options.

As an aid to researchers, Appendix B includes a review of the recent literature that touches on either basic needs for energy or the renewable technologies capable of providing energy to rural Third World villages. Each section closes with a brief analysis of how these studies have raised many legitimate questions about future energy availability and the choice of energy technologies for development; but the studies have not provided satisfactory solutions to these problems. 
SERI 


\section{SECTION 2.0}

\section{A PROCESS FOR MATCHING ENERGY NEEDS WITH RENEWABLE ENERGY TECHNOLOGIES}

This section presents an analytic structure for matching basic human energy needs with appropriate renewable technologies. A general framework has been developed that applies to all developing nations and is not oriented to any specific geographical area, climate, or culture.

The primary concern is with the particular problem of selecting energy technologies for projects funded by national governments, international organizations, research institutes, or nonprofit foundations and philanthropic groups. Such organizations and agencies have a pivotal role in the introduction and development of most energy-producing technologies in developing countries. This is particularly true for electrical generation and transmission, but it now is true for fossil fuel exploration and production. The public sector also has introduced moderately capital-intensive, energy-consuming devices in the agricultural sector such as tube wells and small-scale agricultural process heat systems, although the importance of this role has varied from country to country.

\subsection{CENTRAL ASSUMPTIONS UNDERLYING THE PROCESS}

This report concentrates on the decision-making process in governmental and philanthropic sectors and considers the social and environmental as well as the economic benefit of development projects. Two basic assumptions about the proper role for outside stimulation of development and technology selection already have been noted; they are outlined and defended here in detail before proceeding with the step-by-step outline of the proposed technology selection procedures.

\subsubsection{Basic Human Needs Approach}

A central tenet of the recent development programs of many Third World nations and of most foreign assistance and multilateral finance organizations is that priority should be given to projects that directly assist in providing life-sustaining goods and services for the poorest segments of the population. An international group of development planners described this orientation as follows:

The basic needs of human beings in any society include food, water, clothing, shelter, health, sanitation, and education ... The Basic Human Needs (BHN) development approach, then, is an equity-oriented effort at providing, in a sustainable way, these essentials of life to all people. The impoverished members of society, especially in the least developed countries, are the primury turgets of the BHN approach. (Colglazier et al. 1978)

Any projects using the method developed in this paper are assumed to be designed from a BHN perspective. This underlying assumption has important implications for the report: the matching process focuses exclusively on meeting the energy requirements of basic human needs. Infrastructure-creation tasks are considered only if they contribute directly to the provision of energy for basic life-sustaining goods and services, such as adequate food, shelter, space heating, clean drinking water, hot water for bathing and 
disinfection, and protection from disease. For example, the development of telecommunication or road networks is not considered, although these may be important components of an overall national development program, but the provision for irrigation water and rural sanitation is examined. The focus is on basic rural energy needs because the majority of the poor in developing countries live in the rural subsistence agricultural sector that does not have ready access to centrally generated energy sources or fossil fuels.

An important corollary of the BHN approach is that the choice of technology is governed by the requirements of fulfilling basic needs rather than just by the desire to create markets for existing technologies. This approach requires that energy needs be identified and ranked before the selection process begins and that the project planner avoid selecting technologies until the total impact is estimated. Since the BHN approach is directed toward the poorest segments of the population, the planner needs to analyze who receives the benefits of the energy system and examine the physical outputs of the energy technologies.

Although the method in this paper has been designed specifically to assist in the selection of renewable energy technologies for basic human needs, the process described in Sec. 2.2 also could be employed for other types of energy applications in developing countries. To do so, the criteria (and, in some cases, the definition of the characterization criteria) for matching needs and technologies would have to be redefined to suit the application.

\subsubsection{The Necessity of Matching Characteristics of Needs and Technologies}

This report is predicated on the deslrabllity of curefully mulcling the characteristics of a range of renewable energy technologies with the site-specific characteristics of each basic energy need. There are three major reasons for this approach. First, the output of most small-scale renewable energy systems is inleimittent and variable. When the quantity or timing of energy output diverges from the pattern of demand, some form of mechanical or electrical storage must be used. This can adversely affect the cost, reliability, and maintenance of a renewable energy system. A careful matching of output with temporal and spatial requirements can minimize storage.

Second, each need requires particular energy forms: heat, mechanical shaft power, electricity, or combustible gas. Some tasks can use more than one form; i.e., lighting can be provided by electrlcity, a llquld fuel luntein, Oil a combustible gas. Othere require a particular energy type, such as low-temperature heat for crop drying. Energy can be changed from one form to another through conversion, but this increases the total cost, decreases the overall system efficiency, and increases the complexity and maintenance requirements of the renewable energy system. An energy source may include energy conversion if it assists in the coupling of a technology to an identified need, but this must be determined on a site-by-site analysis.

The third rationale is that the acceptance and use of a new technology is more rapid in a rural Third World setting if its introduction causes little disruption in the existing practices and customs of the villagers. By first investigating a villager's particular energy needs, the matching process can assist the analyst in selecting a technology whose output fits traditional patterns. 


\subsection{STEPS IN THE NEEDS/TECHNOLOGY MATCHING PROCESS}

In this section, a five-step matching process is outlined to guide the choice of a renewable energy technology for any given basic rural energy need. The process is shown graphically in Fig. 2-1; a discussion of the components of each phase follows.

The matching process should be viewed as an integral part of the energy project selection. Since each developing country's government and each development assistance organization has its own planning process, this report cannot detail how the proposed matching technique fits into each institution's internal project review techniques.* Some parts of the matching process, like the social and cultural assessment components, already may be required in the planning procedures of some institutions. The development organizations may want to employ all aspects of the matching process to establish a thorough planning mechanism for energy projects. Section 4.2 discusses further the incorporation of this process into existing institutions.

\subsubsection{Step One: Choice of Program Goals}

The energy technology selection process must consider a country's development goals and programmatic objectives. National leaders and planners determine the energy needs of the country and from these needs determine the long-term goals of the development program. Energy is an intermediate good used to provide services and to perform needed work. In areas where more energy is needed than is currently supplied, the development of a new energy source may be set as an important programmatic goal. Where new conventional electrical generating capacity or additional fossil fuel resources is expensive, the goal may be to provide new renewable energy sources or increase the efficiency of current renewable energy technologies. In the second case, there also may be substantial private economic incentives to use new energy systems or energy conversion techniques.

Where a renewable energy provision has been identified as a major program objective, development planners rank energy and other priorities in order of importance. Since scarce resources such as capital, foreign exchange, skilled labor, management expertise, or raw materials normally are rationed, this weighting of objectives allows the planner to allocate the available resources to the most important (often meaning cost-effective) tasks first. This process determines what resources will bé devoted to the energy projects. However, it is important to remember that energy is an intermediate good, not an end unto itself. For each energy project, the planner must keep in mind one central question: to what end am I introducing one or more energy technologies? Without such objectives it is impossible to evaluate the success of a technology introduction. In the final analysis, the important question is not how did the system perform, but how close did it bring the user to the initial development goals.

Identifying project goals also marks the beginning of consultations with the final consumers, the local villagers. The consultation process varies, depending on the social and political structure of the local community, but should be an integral part of the choosing and ranking of project goals.

*For an excellent recent example of the integration of a rural energy survey and a renewable energy technology/basic needs matching process, see Burrill, Forman, and Gomez (1980). 
Figure 2-1. NEEDS/TECHNOLOGY MATCHING PROCESS

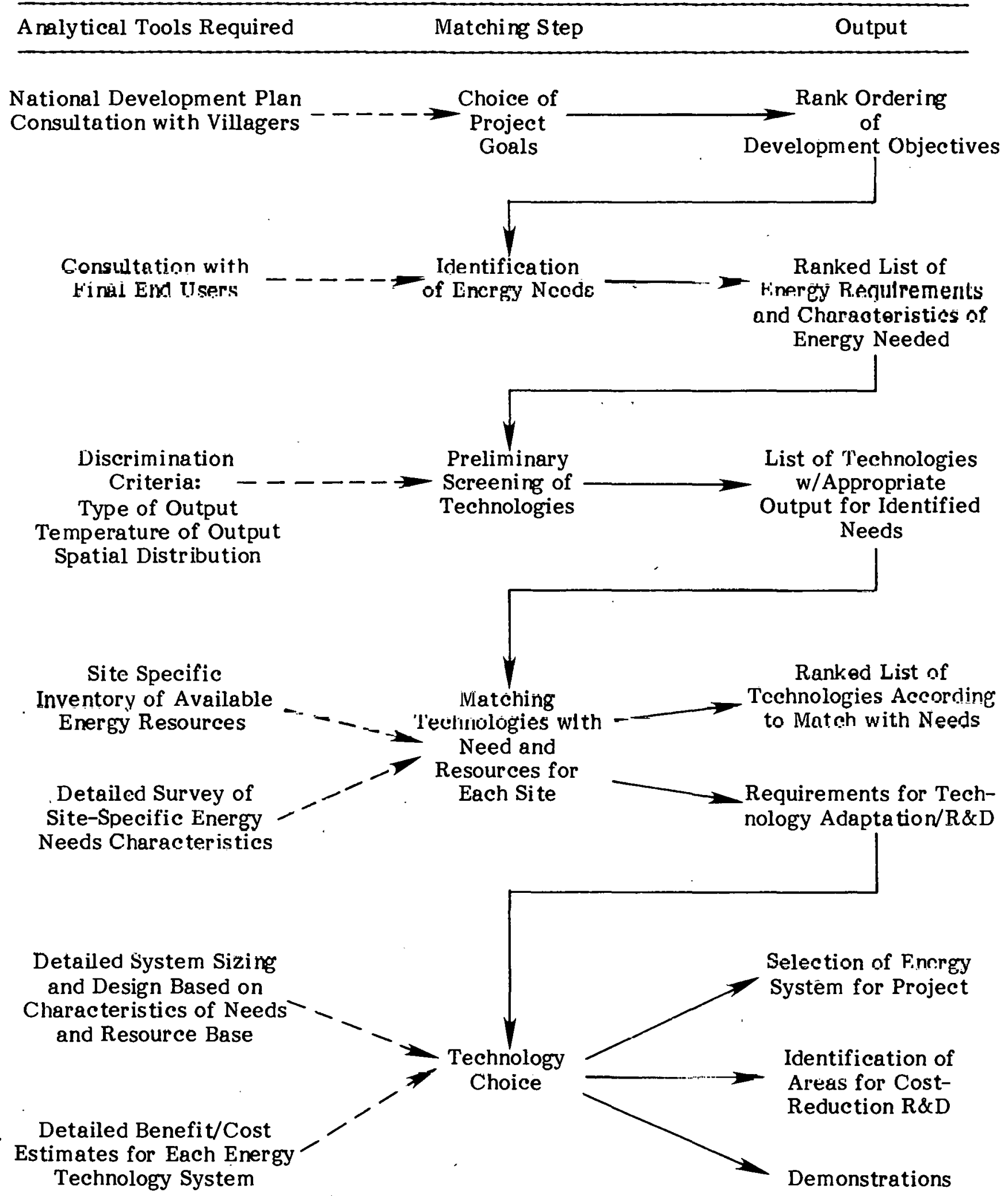




\subsubsection{Step Two: Identification of Energy Needs}

Having defined the development goals, the next task for the planner is to determine which needs are of prime importance to the villagers and what particular activities require energy. Again, consultation with the villagers is essential to prevent the imposition of outside biases. Too of ten project planners autonomously decide what is needed; e.g., street lights, gas for cooking, an educational television receiver. Because much or all of the capital cost for the renewable energy systems is provided initially by governmental agencies or other funding sources, the villagers are likely to accept what is offered. However, if they do not have a substantial role in selecting what needs will be met first, the villagers are not likely to actively support the technology introduction process, assist in any necessary modifications, or maintain the system once it is installed.* Broad-based participation also ensures that the benefits provided by the energy technology are not appropriated by a small number of villagers based on their monopolization of one or more factors: land, capital, elected or traditional authority, education, etc.

A brief analysis of the fundamental characteristics of energy needs-how much, when it is required, where it must be delivered, and in what form-also should begin at this point to facilitate the initial screening of technology options. A much more detailed assessment of characteristics of energy needs is undertaken in Step Four.

\subsubsection{Step Three: The Preliminary Screening of Technologies}

At this point, the development planner or project manager begins to use the available technical support. Having defined and ranked the energy needs that should be satisfied, the planner and the technical support unit can begin to narrow the range of renewable technologies capable of producing the required energy.

For this preliminary screening the planner can use analytic tools the authors call discrimination criteria. These criteria characterize energy needs and technologies that are relatively insensitive to site-specific variations or social and cultural patterns. Once the characteristics of the energy need are defined using these criteria, energy technologies can be examined using those same criteria and preliminary matches can be identified. The major advantage is that discrimination criteria can eliminate inappropriate technologies before extensive site-specific data have been collected. The three major criteria for each need ale:

- type of energy output required,

- temperature of energy required, and

- spatial distribution required.

Each criteria inposes a different screen on the full list of technology options. The first criterion selects those technologies that provide the required energy form to meet the need without energy transformation. The second criterion identifies energy systems that produce a sufficient level of thermal or kinetic energy to perform the task required. For example, an absorption refrigeration system and a pottery firing kiln require temperatures of $100^{\circ}-130^{\circ} \mathrm{C}$ and $250^{\circ}-500^{\circ} \mathrm{C}$, respectively. Both are beyond the normal

\footnotetext{
*Substantial project data suggests that local financial participation in the building or purchase of a system may be crucial to later maintenance and adaptation.
} 
performance range of flat-plate collectors, and the higher temperature range is beyond all but a small number of technologies including biogas generators, direct biomass combustion, concentrating collectors, and, possibly, resistance electrical heating from a large-scale generator. The third criterion, spatial distribution, addresses the problem of providing the energy where it is required. If energy must be delivered to several sites, the technology options are reduced rapidly to those sources whose output can be moved efficiently from a central location--such as electricity, combustible liquids and solids, and, to a lesser extent, combustible gases-or that can be located at each site.

By using these criteria, the planner and energy advisor can reduce the technology options for each identified need. The criterion for the energy type is particularly useful in identifying technologies that do not require energy transformation. The spatial distribution criterion helps ensure that technologies are selerted that most easily and efficiently serve the required locations. An ideal technological option includes all three need characteristics. Most feaslble chulces readily match the need on two of the three criteria.

Once certain technologies favorably match a need, then only these technologies need to be evaluated on the other, more site-specific criteria. Consequently, the use of the discrimination criteria allows a planner early elimination of certain technological options, thereby reducing the time and resources required to assess each site.

Of course, the matching problems posed by the discrimination criteria can be overcome by using energy-transforming and power-conditioning equipment. Mechanical wind power, which is not easily distributed over great distances, conceivably can be used for dispersed cooking sites by converting the power to electricity and letting it power electric-resistance hotplates or stoves. This option is doubtful, given the efficiency losses and cost of such a system, but the final screening is determined in Steps Four and Five of the matching process.

\subsubsection{Step Four: Matching Technologies with the Needs and Resource Base of Each Sitc}

This step is the heart of the matching process. It provides the data on energy needs and technologies that determine their compatibility in a particular location. Here, most resources for the project assessment, both in terms of funds and personnel, is expended. Planners and technologists together with a counterpart group of villagers inventory what local renewable resources (i.e., sunshine, wind, water flow, etc.) are available to power the technologies still under consideration. The energy resource base is evaluated on the basis of the following three general criteria:

- physical availability-size of the resource base and current demands upon the resource;

- variability-changes in the resource on a daily, weekly, seasonal, and annual basis; size of swings as a percentage of average resource availability; and

- constraints on use-ownership of the resource, historical, cultural, or economic restrictions on use; conflicting or multiple claims on the same resource.

A more detailed list of site-specific criteria describing the energy resource and need is given in Sec. 3.3. 
Acquiring accurate resource-availability information covering an entire year can be a formidable task, particularly for renewable energy systems whose sizing is highly dependent on the amount of local resource, such as wind energy conversion systems and smallscale hydroelectric generators. At this stage, preliminary observations can be made and simple measuring instruments installed for villagers to monitor. Readings collected over several months or longer greatly assist in the final design of the selected technologies and in the sizing of any storage and energy conversion devices.

While the resource assessment is being conducted, other members of the project team can detail the characteristics of each of the local energy needs. The information collected provides descriptions of all three discrimination criteria and other pertinent criteria. The criteria used to describe the energy needs are virtually identical to those used to characterize the output of the technologies, so that needs and energy systems easily can be compared and matched. The focus of the data collection is the current pattern of energy use: what quantities of fossil and renewable fuels are needed and what human and animal energy is consumed, in what form, at what time, and for what purposes. In a small rural community, this information can be gathered rapidly by various survey methods, community discussions, or a combination of the two.*

The information collected in this phase of the project should be useful not only for the selection of technologies for an individual project but also for the later evaluation of the social and economic changes produced by the introduction of the new energy systems. Such information should be collected uniformly so that the results are comparable from project to project. There has been a great deal of research in the United States on developing a common procedure for conducting surveys of rural energy needs and resource availability. An effort is being directed toward creating of a survey instrument that is broadly applicable and site specific.**

With information on the local resource base and the characteristics of the local energy needs, the project manager and energy technologist can use an organized matching process to select the energy system or group of systems that most closely matches the needs. At the same time, the project team can identify the research and development work, field-testing, or technology adaptation that will improve the match between the needs and the candidate technologies. Where possible, this adaptation can begin while the final detailed plans for the implementation of the project are being completed. This minimizes delays in delivering the energy technology to the villagers. Incentives that will make adoption of the energy system more attractive to users could also be considered at this stage. Preliminary in-country training programs for the installation and maintenance of the renewable energy systems also can begin at this time so that the infrastructure will be in place by the time the systems are completed or purchased.

*Based on work in Swaziland, Thomas Graham (1979) found that house-to-house surveys were of ten inappropriate and $m$ isleading due to cultural strictures.

**For a good example of an approach to rural energy surveys, see Donovan, Hamester, and Rattien (1979). The U.S. National Academy of Sciences, in conjunction with the U.S. Agency for International Development, conducted a workshop in January 1980 that discussed energy survey methods in the rural, urban, industrial, and transportation Ecetore. 


\subsubsection{Step Five: Teehnology Choice and Installation}

With the detailed local data, the planner now can specify the renewable energy systems. This includes sizing each system, calculating the storage required (if any) to reliably meet the energy needs, coupling the new energy system to existing power sources, and providing energy conversion where needed. For locally designed and fabricated systems, detailed designs incorporating readily available materials have to be developed and tested.

Once the detailed specifications of the systems have been completed, traditional analytic tools for assessing preproject feasibility, such as social benefit/cost analysis, can be employed. Major problems will arise in quantifying certain factors, particularly benefits, because of the lack of information (the value of the traditional fuels displaced) and site-specific data (the energy output of an installed system in a particular location). Nonetheless, even rough estimates of the cost/benefit ratio will assist not only in the final selection but also in comparing these systems with fossil-fueled and traditionally powered systems. The emphasis in this phase is on minimizing costs and maximizing efficiency within the constraints imposed by the energy needs and other national development priorities; e.g., expanding rural employment to slow rural-urban migration. This might favor those systems that can be assembled on-site using labor intensive techniques.

This last stage in the technology selection process corresponds to two prefunding stepsthe benefit/cost analysis and the engineering feasibility study-that are performed routinely for most major development projects today. It produces the detailed specifications for construction, system procurement, and project management. This phase also identifies additional research and development needed to lower the cost of renewable energy systems and still match the characteristics of the needs. For example, low-cost manual tracking mechanisms.for concentrating collectors or solar cookers can replace automated tracking subsystems. Field demonstrations of these proposed cost-reducing modifications may be required to determine if they are durable, reliable, and locally acceptable.

\subsection{ABBREVIATING THE TECHNOLOGY SELECTION PROCESS}

The needs/technology matching process just described provides a wealth of information to the development planner and renewable energy researcher. Tailoring the technologies to site-specific energy needs should ensure that the energy provided is useful and welcome. Involving the local villagers in each step of the matching process helps identify and solve social, cultural, and religious obstacles to the technology diffusion proccas.

The collection and analysis of performance and baseline data is important for the sponsoring development agency or donor organization, particularly when the organization introducing the technology is relatively unfamiliar with it. Data are required to evaluate the system's success in advancing the development objective. Without information on preexisting energy consumption patterns, it is difficult to determine the impact of this particular technology on the lives of the energy users. The information on the resource base also is important for evaluating the technical efficiency of the particular design and for sizing systems for particular end uses.

Each step expends time and resources. The steps also may introduce activities or concepts that are unfamiliar to the sponsoring organizations: rural needs characterizations, time-series data on village energy resource availability, user-defined needs, and locally 
designed and constructed energy systems. The combination of cost and demands on staff may lead the project designer to eliminate one or more steps in the process.

The most radical form of truncating the matching process is to send a team of outside consultants to a site to examine the feasibility of installing one or more predetermined, commercially available systems without assessing the needs of the area beforehand.* Such a compression of the process may produce serious problems for the project manager. The adoption of the technology is influenced heavily by how well it serves the villagers' needs and how quickly it is adapted to the particular site requirements. The neglect of these factors in the past, along with unanticipated maintenance requirements, has led to abandoning many such systems installed in remote areas. A complete technology selection process would help minimize the possibility of such abandonment. A complete analysis may prove impractical, either because of a time restriction or because of the small size of the project. However, for larger projects with normal planning horizons, a major data acquisition and evaluation effort is both feasible and costeffective. The additional expense and time required to conduct Steps One through Four may be recovered by reducing the information gathering required in Step Five. Early acquisition of this information also eliminates the possibility of returning and assembling it after the fact.

*Photovoltaic arrays, wind energy conversion systems, and other decentralized electric technologies are the most common prepackaged energy systems. 
SEPI* 


\section{SECTION 3.0}

\section{A GENERAL ILLUSTRATION OF THE MATCHING PROCESS}

The needs/technology matching process has been designed for use in a specific location. To illustrate how the process actually works, an initial matching analysis is presented based on the general characteristics of fundamental needs that are applicable to most developing regions. This initial match does not identify which technologies are best suited to a given task in any one developing country site, but is useful to a developing country and foreign assistance officials for the following reasons:

- it illustrates the method for site-specific matching;

- it indicates the types of information that must be collected to fit needs and technologies for a certain location;

- it shows which technologies may be potentially useful in providing energy for certain basic needs; and

- it indicates where further research is needed on

- the performance and energy use of basic need tasks, and

- the applications of renewable energy technologies on rural, developing villages where low-cost and small-scale technologies are required.

The initial matching process employs general characteristics of needs and technologies that are not descriptive of any particular region. By examining research on how basic human needs are met in diverse locations, it is possible to identify certain common characteristics that describe the seasonal, temporal, and energy requirements for basic needs. The cultural factors are not generalizable and, because of their importance, must be studied for each location. In the initial matching process the general basic need characteristics are compared and matched with the characteristics (i.e., form of energy output, temperature, spatial distribution) of the technologies that are not dependent on climate conditions. When initial matches between the need and technology characteristics are found, the technology is noted as a potentially good source for meeting the basic need. This is contingent on cultural and climate factors as well as the availability of the renewable energy resource required to power the technology.

Portions of the procedure have proven difficult to execute in such a general case. This is particularly true of factors that are highly dependent on the local climate, seasonal variability, time of day, etc. In these cases, a range of possible conditions is presented. Storage was found to be such an important factor, because of its impact on the ability of a technology to perform certain tasks and on total system cost, that it has been included as a separate option for each technology.

Cost has proven to be a particularly difficult problem because of the technological options included within each category, which range from simple field-assembled systems to manufactured products. The focus is on manufactured systems for two reasons: their costs are known and they form the upper limit of expenditure to meet a given need. This does not imply that they are necessarily more (or less) appropriate; that depends on the local circumstances and requirements for energy. Wherever possible, the cost figures for village-built systems are given for comparison. 


\subsection{IDENTIFICATION OF BASIC NEEDS FOR ENERGY}

To illustrate the matching of basic needs/technologies, research has been assembled on two topics: the characteristics of basic needs and the properties of a number of renewable energy technologies. Literature on basic human needs, their definition, and their importance for development has been reviewed. From this review and discussions with development planners and foreign assistance officials, $a$ list of seven basic needs has been chosen for analysis. These needs are universally essential for human and animal subsistence, health and sanitation, and agricultural and village industrial production. They are listed in Table 3-1. Of course, there are a great number of other needs that could be added to this group depending on individual site requirements, such as power for small-scale village industries and fertilizer production.

Table 3 -1. BASIC NEBDS FOR ENERGY

\begin{tabular}{ll}
\hline \multicolumn{1}{c}{ Type of Activity } & Identified Need \\
\hline Food Preparation & $\begin{array}{l}\text { Cooking } \\
\text { Drying } \\
\text { Processing }\end{array}$ \\
Health Maintenance & $\begin{array}{l}\text { Provision of potable water } \\
\text { Space heating } \\
\text { Refrigeration }\end{array}$ \\
Agricultural \& Village & Irrigation \\
Industrial Production & \\
\hline
\end{tabular}

Specific research has been done on how each basic need is performed, drawing upon literature that describes the economic, social, historical, cultural, and religious aspects of basic need fulfillment in particular developing countries and villages. Information has been collected on the set of characteristics for each basic need that best describes the conditions under which the basic need is fulfilled.

\subsection{RENEWABLE ENERGY TECHNOLOGY ALTERNATIVES}

A list of small-scale renewable technologies available to meet one or more of these needs has been compiled. Although meant to be comprehensive, this listing does not include experimental systems, such as metal hydride/flat-plate collector combinations, because a successful working model has not yet been constructed. The seven technologies selected are listed in Table 3-2, along with the type of energy that normally is produced without power transforming equipment. 


\section{Table 3-2. RENEWABLE ENERGY TECHNOLOGIES} AND THEIR OUTPUT

\begin{tabular}{ll}
\hline \multicolumn{1}{c}{ Available Energy Technology } & Type of Energy Produced \\
\hline Flat-plate solar collector & Heat (hot water or air) \\
Concentrating solar collectors & Heat (hot liquids or steam) \\
Biogas generator & Combustible gas \\
Wind energy system & Electricity, shaft power \\
$\begin{array}{l}\text { Small-scale hydroelectric/ } \\
\text { hydrokinetic generator }\end{array}$ & Electricity, shaft power \\
Photovoltaic cells & Electricity \\
Direct biomass combustion & Heat or process gas \\
\hline
\end{tabular}

This is not an exhaustive list of the technologies or the possible forms in which output can be generated. Fuel-cell systems as well as energy devices using wave and tidal power have been proposed by some researchers for remote locations. Wind-mills have been constructed to produce heat directly without mechanical power. Concentrating photovoltaic cells can generate considerable supplies of useful heat as the by-product of their electrical generation. The seven technologies examined are the major alternatives available today to individuals or organizations seeking to install decentralized renewable energy syste $\mathrm{ms}$ in remote sites.

\subsection{DEVELOPMENT OF CHARACTERIZATION CRITERIA}

Twelve characteristics were developed that describe each basic need based on the physical and temporal requirements for meeting the need, the amounts and kinds of energy that have been and could be used, the traditional social and cultural context of meeting the need, and the cost restraints for fulfilling the need in a new manner. This set of descriptive characteristics, which is referred to as characterization criteria in this report, provides the context for describing the essential conditions for satisfying each basic need. The characterization criteria are restricted to those that are also appropriate for describing the renewable energy technologies, their essential properties, applications, and climatic and economic requirements. As explained in Sec. 2.2.3, three criteria have been selected as discrimination criteria, since they are less site-specific than the other characterization criteria. The remaining nine matching factors are divided into three categories: temporal and climatic criteria, social/cultural/environmental criteria, and cost considerations. Table 3-3 lists the twelve criteria, explains how the characteristics apply to basic needs and energy, and gives the unit of measure for each characteristic.*

*A somewhat different approach is taken by researchers of the East-West Center, who have developed criteria for comparing and evaluating alternative energy systems and classifying these criteria into four major categories: energy quality and quantity, temporality of tasks and technologies, spatial relationships between energy-consuming technologies and the energy-producing technology and energy resources, and versatility of energy technologies. See Smith, Santerre, and Schlegel (1980) for details of these criteria and for a presentation of the variation on this analysis. 
It must be emphasized that these criteria are highly site-specific. This is true not only for each characteristic, since daily energy use will vary from village to village, but also for the relative importance of each criterion. In some locations, the time of day may override all other considerations for certain tasks (cooking, for example), while in other places the key consideration may be the spatial distribution (communal cooking versus individual home units). Such priorities can be determined only by direct consultation with the energy consumers. Nonetheless, the overall criteria includes all the characteristics reported by field researchers that affect the success of the introduction of a new technology into a rural village setting. 
Table 3-3. CHARACTERIZATION CRITERIA

Criteria

Basic Needs
Renewable Energy

Technologies

Unit of Measure

\section{Discrimination Criteria}

Type of output

Temperature of output

Spatial dispersion

\section{Seasonality}

Time of day.

\section{Duration}

Sensitivity to interruption

Form of energy that can satisfy demand

Level of heat to perform required niork

The number of locations per village needed for the performance of the basic need task

\section{Form of energy produced}

Range of temperature of energy system output

Capability to distribute the energy output produced by the technology

\section{Site-Specific Temporal \& Climatic Criteria}

Time of year when the energy demand occurs

Time of day when energy is required to perform the basic need task

Duration of time per day required to perform the basic need task

Length of time the performance of the task can be halted
Time of year when the resource produces useful energy output

Time of day when the useful energy is produced

Duration of time the technology provides useful energy during the day

Variability of output of the energy source
Not applicable

${ }^{\circ} \mathrm{C}$

Number of sites per village required

Growing season, nongrowing season, or all year long

Morning, daytime, night, or 24-hour day

Number of hours per day

Can be inter- Variable rupted or or not cannot be variable interrupted 
Table 3-3. CHARACTERIZATION CRITERIA (concludəd)

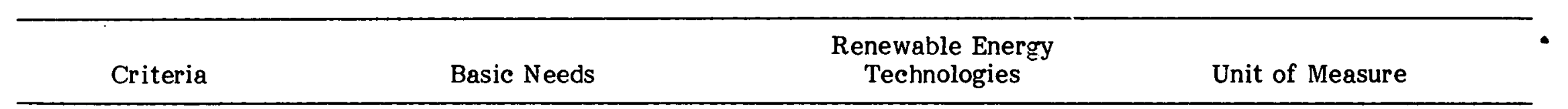

\section{Site-Specific Social, Cultural/Environmental Criteria}

Usage by type of person \& religious influences

Traditional energy sources used

Environmental and ecological factors
Historical, social,
Persons participating in the basic need task affected by changing the energy source

Historical, social, and religious requirements/ basic needs are met

\section{Sources of energy used to sat isfy village require- ments}

\section{Climatic and resource} conditions that limit local ability to satisfy needs or that alter relative importance of basic human needs customs that affect how
Persons likely to be involved in operating the renewable energy technologies and their various skills

Traditional patterns that could create resistance to the use of the energy technology and energy use

Traditional use of renewable energy sources

Traditional technologies used to protect renewable energy sources

Factors that influence energy system performance, durability, maintenance requirements, etc.; also factors that are affected by the installation of an. energy system or the reallocation of resources
By sex, age, and class

\section{Description of the} historical, social, \& religious customs that affect basic needs

Units consumed per capita or per task (kilograms of firewood, charcoal, dungs, etc.)

\section{Qualitative descriptions}

Costs given in dollars (and/or person days) per unit of work or per unit of output; social cost qualitatively described

\section{Cost Considerations}

Cost energy technologies (given
Costs of the technology's local application
The cost limits for new social costs of traditional and conventional energy used for basic need requirements and the firancial resources available to the village) 
SECTION 4.0

\section{OBSER VATIONS, RECOMMENDATIONS, AND CONCLUSIONS}

\subsection{RESULTS OF THE ILUSTRATIVE MATCHNG PROCESS}

In this section the outcome of the matching process is presented in capsule form. The complete matrix of technology characteristics versus need characteristics is contained in Appendix A for four sample needs: cooking, crop drying, food processing, and refrig-. eration.

This section also offers summary conclusions on the results of the matching process for each of these basic needs, as well as for the provision of potable water. For each need, an outline is provided for the key characterization criteria, the best technology match for the need, alternative technologies, and the problems with these alternative energy sources. In addition, site-specific social, cultural, and environmental considerations are noted. Preliminary indications of needed basic $R \& D$, demonstrations, and required technology modifications are given at the end. Section 4.2 offers general observations on the usefulness of the matching process to development planners and program managers, and Sec. 4.3 provides recommendations on the next steps required to refine and apply the matching process specified in this report.

Many of the needs/technology combinations that emerge from the matching process are time-tested and traditional: biomass combustion for cooking, windmills for water pumping, flat-plate collectors for crop-drying, etc. Acknowledging these matches does not necessarily aid the development planner or project designer. However, note that these technologies have been employed in the past and are being used today precisely because their output characteristics, reliability, and cost are close enough to the pattern of need to satisfy the end-user. It also demonstrates that certain new technologies have the potential to displace energy systems whose use has undesirable side effects, such as deforestation caused by overcutting vegetation for firewood in arid or mountainous areas. Problems with several of the potential technologies are indicated for each need and one or two areas are singled out for increased research, development, demonstration, and commercial production.

\section{COOKING}

\section{Results of the Matching Process}

Key Characterization Criteria. Temperature of output, time of day of output, and all sociocultural criteria.

Best Matches with Need. Biomass combustion and biogas generation.

Other Possible Matches. Wind (electric) and small-scale hydroelectric generation and direct concen trating collectors (solar cookers).

Advantages of Best Match Technologies. Biogas and biomass energy systems do not depend directly on climate variations, but they do require a supply of organic material, animal wastes, or agricultural residues. These materials can be stored, eliminating the 
need to store output energy. Biomass combustion is the most acceptable and convenient technology, providing that sufficient supplies of fuel can be obtained easily and without environmental damage. The exception is the combustion of dung and crop residues, since it destroys the nutrient value of these wastes and lowers soil fertility. In areas where there is widespread reliance on dung and residue combustion, biogas production is preferable despite its greater complexity and capital costs. An indirect answer to shortages of combustible forest products may be to introduce more efficient energy devices, such as Lorena stoves, or the acceleration of biomass production through special plantations.

\section{Problems with Other Possible Energy Sources.}

- Solar Cookers--Can only cook during daylight hours and outdoors in intense sunlight; must adjust cooker every few minutes to track sun; moderate to high capital cost; cannot use for many traditional foods.

- Electric Technologies-Extremely high cost per unit of delivered energy due to conversion inefficiencies, losses during transmission, and losses from resistance heating systems; also, high cost and maintenance of storage required when there is insufficient power for cooking (i.e., cloudy days and evenings).

\section{Site-Specific Social/Cultural/Environmental Considerations}

Social and Cultural. Cooking is one of the most culture-bound human activities. Food preparation, serving time and place, food flavor, and cooking participants of ten are established by long tradition and, therefore, are resistant to change. Social and religious customs may dictate all of the characteristics of the energy demand and may eliminate certain technology options even if the energy output is a good match for the pattern of demand.

Environmental. Rising populations and accelerated use of firewood have been major factors contributing to deforestation in certain areas of the developing world. This is a major concern in semi-arid and arid areas and in mountainous regions where desertification, massive erosion, and siltation of major watersheds are occurring.

\section{R\&D, Demonstration, and Technology Modifications Needed}

Basic R\&D. Solar cookers that can be controlled from indoors or that efficiently move heat to a covered (and socially acceptable) location; accelerated development of small, efficient, low-cost, low-maintenance batteries.

Demonstrations. Iligh-efficiency woùd stüves; electiłic l'esistuıce cuuking units.

Teehnology Modifications. Use of new materials to lower the cost and maintenance of family-sized biogas generators. Also biogas system modifications to allow optimal operation in colder climates. 


\title{
CROP DR YING/FOOD PRESERVATION
}

\author{
Results of the Matching Process
}

Key Characterization Criteria. Form of energy, temperature of output, duration of output.

Best Matches with Need. Flat-plate collectors and biomass direct combustion.

Other Possible Matches. Biogas generators and the solar electric technologies (photovoltaics, wind, and small-scale hydroelectric generation) with storage and resistance electric heating systems.

Advantages of Best Match Technologies. Flat-plate collectors and biomass combustion directly produce low to moderate temperature hot air without any energy transformation or storage devices. Both require small amounts of capital and are simple to maintain and operate. They are similar to traditional drying techniques so do not experience cultural acceptance problems. They are superior, however, to traditional open-air methods because their drying speed and enclosed structure lowers spoilage and decreases insect infestation. Also, they can be used in either dispersed or centralized drying operations:

\section{Problems with Other Possible Energy Sources for Cooking.}

- Biogas Generators-The capital cost of biogas generators plus the need to stockpile feedstock before and during the harvest pose some problems. The cost might be remedied by using the biogas output for other needs during the nonharvest periods. The feedstock problem might be lessened by developing systems that can use multiple inputs or do not rely only on agricultural residues.

- Solar Electric Technologies-The high capital cost combines with conversion losses through the use of resistance electricity. Some storage would probably be desirable but not mandatory.

\section{Site-Specific Social/Cultural/Environmental Considerations}

Social and Cultural. The method of drying may affect the taste of the food. Sun-drying and wood-smoking produce very different tastes and this may influence consumer acceptance. Drying food with gas derived from dung may not be acceptable to certain cultures. Traditional spatial distribution of crop drying is also important. Large batch dryers may be compatible with communal work traditions but unacceptable to farmers accustomed to sun-drying on the family plot. The construction of large central dryers may have profound implications for income distribution if they are owned and operated by wealthy village grain dealers and landlords.

Environmental. Flat-plate collectors and biogas generators are better choices in areas where biomass fuels are scarce and open fires are used for crop-drying. Efficient woodburning or crop residue-burning dryers would also help. For locations with little direct 
sunlight or heavy rains after the harvests, enclosed dryers with biogas or biomass heat sources have advantages over solar cabinet dryers or solar electric technologies.

\section{R\&D, Demonstration, and Technology Modifications Needed}

Basic R\&D. Use of waste heat generated by certain technologies to dry crops during harvest season (large or concentrating PV arrays and biomass combustion for electric power).

Demonstration. Use of solar electric technologies, originally installed for other reasons, to dry crops during harvest season.

Technology Modification. Linkage of biogas generator/biomass combustion device with flat-plate collector to allow crop drying during periods of intermittent rain.

\section{FOOD PROCESSING (Crop grinding, etc.)}

\section{Results of the Matching Process}

Key Characterization Criteria. Form of energy, seasonality of output, spatial distribution, and sociocultural considerations.

Best Matches with Need. Hydro-mechanical power generation (with water storage), wind turbines (mechanical), and biogas generators with modified internal combustion engines.

Other Possible Matches. Photovoltaic systems and concentrating collectors with Rankine cycle or Stirling cycle engines.

Advantages of Best Match Technologies. All three technologies can provide high torque, low-to-medium rpm shaft power for traditional processing techniques (stone grinding, seed crushing, shelling, etc.) without the need for power conditional equipment. Also, these energy sources easily can be adapted to power higher rpm modern hammer or burr mills. Biogas generators and hydromechanical systems can provide shaft power on demand, providing there is a sufficient resource base and adequa te storage. All three technologies are ideally suited for centralized, village, or neighborhood processing centers however, they are not necessarily appropriate for powering individual household mills since the energy produced must be distributed to many sites. Because the time of day that processing can be performed is normally flexible, daily fluctuations in the resource base (especially wind energy converters) are not a major concern providing there is enough power to process the crop prior to damage from moisture, insects, etc.

\section{Problems with Other Energy Sourees for Food Processing.}

- Photovoltaic Systems-The extreme high cost per unit of output is only partially offset by the ability to size the PV array exactly to the demand of the food processing equipment. This high cost is due, in part, to the inefficiency of using electricity to produce shaft power; energy transformation would be logical only if the power had to be transmitted either from a remote producing site or to a number of end-use locations (i.e., household grinding mills). 
- Concentrating Collectors--Current systems are inefficient, due to the need to transform heat energy to mechanical shaft power or electricity. Also, there is a need for complex tracking mechanisms to optimize performance and for frequent maintenance on the tracking mechanism and the system components that transform the heat to mechanical power.

\section{Site-Speeific Social/Cultural/Environmental Considerations}

Social and Cultural. The preparation and processing of food is subject to many of the cultural and social restrictions that affect cooking. Social customs may be particularly important in determining the spatial distribution of food processing, dictating either a central location (normally a village mill) or in each household. The method of food processing also may be determined by tradition or religious restrictions and practices. Moreover, the processing method affects the texture, cooking characteristics, and flavor of the final product. For example, fine flour produced by high-speed grinding tastes and bakes differently than coarse flour created by mortar and pestal hand crushing. Finally, mechanized grinding may have a profound impact on the allocation of work and free time within a community. Hand grinding and crushing are very labor-intensive and of ten are performed by women. Mechanization may lead to a transfer of this work to village men or to a professional miller.

\section{R\&D, Demonstration, and Technology Modifications Needed}

Basic R\&D. Low-maintenance, low-cost, nontracking concentrating collectors coupled with efficient engines to produce shaft power from heated gases or liquids; internal or external combustions designed to operate efficiently on biogas (50\%-60\% methane).

Demonstrations. Small household grinding units coupled with individual PV arrays or with power distributed from central PV or hydroelectric generators.

Technology Modifications. Development of modular, portable food processing units that can couple with a range of power inputs ranging from hydromechanical shaft power to human and animal power.

\section{REFRIGERATION}

Results of the Matehing Process

Key Characterization Criteria. Temporal considerations (especially 24-hour reliability) and climatic conditions.

Best Matches with Need. Small-scale hydroelectric generation, biogas generators, and biomass combustion.

Other Possible Matches. Wind turbine (electric) and photovoltaics, both with battery storage, and concentrating collectors with storage, either heat exchanger fluid or electricity. 
Advantage of Best Match Technologies. Refrigeration demands a constant energy source on a daily and seasonal basis. A technology must have either a constant output to fuel the refrigeration unit or sufficient storage to compensate for periods of inadequate or nonexistent output. Small-scale hydroelectric generators can meet these criteria in many locations with moderate impoundment of water, and will provide electricity for existing $\mathrm{DC}$ or $\mathrm{AC}$ refrigeration units. Biomass combustion units producing either heat or electricity have similar reliability although they require constant feeding and some storage during periods of maintenance and repair. Biogas generators produce a gas that can be used to power existing refrigeration units; however, there is a normal daily fluctuation in the output. Small amounts of the gas can be stored to smooth out these irregularities. All these systems meet the criteria of producing sufficient heat to power an absorption chiller.

Problems with Other Possible Energy Sourees for Refrigeration. With the exception of small-scale hydroelectric power, all the solar electric technologies suffer from the cost of storage to guarantee $24 \mathrm{~h}$ /day reliability. This problem may be manageable with wind energy conversion systems in locations with highly regular wind regimes. Of ten, however, seasonal variations make storage necessary for wind systems even in ideal sites. Photovoltaic and solar thermal systems require substantial storage because of the fluctuations in system output within each daily cycle and on a seasonal basis.

\section{Site-Speeific Social/Cultural/Environmental Considerations}

Social and Cultural. Cold storage or freezing of foodstuffs may be a new concept for villagers without previous access to refrigeration. Traditional wavs of preserving foods (particularly meats and fish) may be preferred because of flavor or texture. The need to constantly fuel an energy system (particularly biogas and biomass combustion systems) may conflict with restrictions on working at certain times or with certain materials.(i.e., dung). However, since it can preserve medicines in disease-prone areas, refrigeration may have such a high priority that any system would be maintained.

Environmental. Biogas generators may be preferable to biomass combustion systems because they preserve the nutrient value of agricultural residue and dung while producing a high-quality fertilizer as a by-product.

\section{R\&D, Demonstration, and Technology Modifications Needed}

Basic K\&U. High-efficiency, low-cost durable batteries to store output of solar electric technologies; high-efficiency $D C$ refrigeration units to couple with solar electric technologies.

Demonstration. Small-scale hydroelectric-powered refrigeration units.

\section{Teehnology Modification.}

- natural gas refrigeration units to couple with biogas generators;

- refrigeration units with little maintenance to operate in hostile environments; and 
- cold storage units powered by variable energy sources to cool perishable produce and fish.

Refrigeration or cold storage of perishable foodstuff may affect farmers' incomes because of the high market value of these goods in many developing countries.

\section{PROVISION OF POTABLE WATER}

\section{Results of the Matching Process}

Key Characterization Criteria. Form of energy required and geographical dispersion for pumping; temperature and form of energy for purification.

Best Matches with Need. Wind turbine (mechanical), hydraulic ram, and hydromechanical power generation for pumping; biomass combustion, solar stills, flat-plate collectors, and concentrating collectors for purification.

Other Possible Matches. Wind turbine (electric), photovoltaics, hydroelectric power generation, and flat-plate collectors driving a Rankine-cycle or Stirling cycle engine.

Advantages of Best Match Technologies. There are two problems in the provision of clear drinking water: moving naturally usable water to the point of use or rendering water from brackish or polluted sources into a form acceptable for human and animal consumption. Pumping can be done on an intermittent basis, since the water itself can be stored, making this an energy need that couples easily with a wide variety of renewable energy sources. Mechanical power coupled directly to the pump is the most efficient form of energy and is provided by wind (mechanical) energy converters or by a hydraulic ram (for surface water). Where there is a need for geographical dispersion of the energy (many pumping sites) or a need for a submersible pump (a deep aquifer), electricity provided by a wind (electric) system, a hydroelectric generator, or a photovoltaic array may be more appropriate.

Purification may require either heat energy (for distillation) or electricity (to power a reverse osmosis system). The simplest form of purification is boiling, which kills parasites but does not solve problems of high salt or mineral concentrations. Boiling can be powered best using biomass combustion and biogas generators, since they both provide temperatures over $100^{\circ} \mathrm{C}$.

Water also can be purified by distillation. The original water is heated to produce water vapor which is condensed to produce clean drinking water. Solar stills or concentrating collectors provide the needed heat directly, the former producing vapor below boiling; the latter, steam.

Problems with Other Possible Energy Sources. Solar electric systems require energy conversion systems, which may increase maintenance and complexity. Flat-plate collectors coupled to organic cycle engines are expensive and relatively complex. 


\section{Site-Specific Social/Cultural/Environmental Considerations}

Social and Cultural. A water pumping system may greatly alter the social or work pattem of the individuals who traditionally fetch water (generally women and children). It may also change the distribution of economic and political power within the village if water is a scarce commodity rationed through a market or private monopoly. Cultural traditions about the appropriate temperature of water may also affect acceptance of purification systems. The advent of clean drinking water could affect the productivity and standard of living of villages in areas heavily affected by intestinal parasites and other water-borne diseases. Providing subsurface water sources would greatly facilitate local cooperation with programs to eradicate malaria and other related diseases.

Environmental. Migratory herdsmen often move their flocks in search of water. This leads to the pollution of surface water sources as well as severe overgrazing in periods of drought. Providing a number of subsurface water sources would lessen this, particularly when coupled with irrigation for fodder and pastureland.

\section{R\&D, Demonstration, and Technology Modification Needed}

Basic R\&D. Batch water heaters designed specifically for water purification.

Demonstration. Village-scale water distillation and desalination systems.

Technology Modification. Zero-maintenance pumps to couple directly with wind or hydroelectric systems in areas with harsh environments (high temperature, sand infiltration, etc.).

\subsection{KECÖMMENDATIONS}

\subsubsection{Application of the Matching Process to Village Locations}

The validity of this report's assumptions and prescriptions can only be tested with actual projects in developing countries. 'I'he method and individual characterization criteria could be modified, expanded, or eliminated based on the experience of the project staff and the developing country's planners. Ideally, this field-testing of the matching process could take place within a quasi-experimental project designed so that the factors affecting the project's success can be isolated from alterations in the process. The characteristics and advantages of such a design is discussed in Ashworth (1979). If the experimental design proves to be impractical, results from three or more test sites or separate projects should be used to modify the matching methodology. This would minimize the effects of the environment and culture of any one location. These tests would answer four questions:

- Does the methodology work in its present form or are there major components crucial to technology selection and project success that still need to be incorporated? 
- Can the methodology be simplified? Are there components that can be eliminated without affecting the final technology selection?

- What resources are required from the planning agency, ministry, or donor organization in terms of time, funding, or technical expertise? How does this compare with traditional engineering feasibility studies?

- How does it aid the adaptation of a technology to local needs and environment?

\subsubsection{Survey on Component Costs of the Matching Process}

Many components of this process have been used routinely by one or more development organizations as part of their preproject feasibility studies or project management procedures. For example, in the last three years a number of projects have been initiated by donor agencies that included site-specific inventories of available energy resources and local energy needs characteristics.* Detailed cost engineering estimates along with some procedure for identifying, and of ten quantifying, the accompanying benefits are developed for all but the smallest development projects. Many development organizations use sophisticated mechanisms for incorporating noneconomic criteria (e.g., the impact on the environment, consequences for the role of women, and income disparities) into the project identification and technology selection processes.

Although preliminary technical results on energy need patterns and technology performance are becoming available, little is known about what additional components such as rural energy surveys and renewable energy resource assessments are required from the sponsoring organization and how they affect energy delivery to the village end user. It would be useful to gather such information now through discussions with project managers and consultants used to perform field studies and distribute it to interested development planners. Such information also would help focus discussions currently underway in a number of development institutions on how to integrate components of the matching process into existing internal practices with a minimum of cost and disruption.

\subsubsection{Improving the Needs/Technology Fit}

One of the major advantages of the matching process is that it identifies characteristics of each energy technology's output that are not compatible with the pattern of local energy demand. The nature of the mismatch determines what activities are needed to improve the usefulness of the technology. Where there is a fundamental disparity between the characteristics of the technology output and the energy need, $R \& D$ may eliminate or reduce technical problems and increase compatibility. Where the need/technology fit is theoretically good but major operating difficulties have been encountered in experimental systems, applied research and technology adaptation may overcome climatic factors, decrease maintenance, simplify operating procedures, increase use of local materials, or accommodate local tastes and customs. Third, there may be an apparent good match but little or no operating experience in the country or region or for this particular application. A solution would be field demonstrations with systems installed specifically to gather information on actual performance. Finally, a technological option may provide the required energy but is too expensive for widespread use. This requires efforts to lower delivered per-unit costs through expanded production, increased local manufacture, the substitution of lower-cost components, etc.

\footnotetext{
*For brief overviews of six of these projects, see Ashworth (1979).
} 
The illustrative matching performed for this report indicates a number of specific areas in each of these four categories where immediate attention seems to be warranted. These need-specific requirements have been combined with more general recommendations that also encompass other basic village-level energy needs besides the four used in the sample matching.

\subsubsection{Basic Researeh and Development}

Low-cost, high-efficiency, zero-maintenance batteries. The development of such efficient electrical storage units would increase the attractiveness of all the solar electric technologies for a variety of remote-site, end-use energy needs. The deep-cycle lead/acid batteries currently in use in experimental solar systems today are expensive to buy and maintain and have limited life spans particularly in regions that experience temperature extremes. An alternative is to perfect a nonbattery storage for electrical or mechanical energy.

Solar thermal units to sterilize drinking water. There is a pressing need for research on the use of direct insolation to kill water-borne intestinal parasites and other water-borne health hazards. This can be accomplished by maintaining a water temperature of $65^{\circ} \mathrm{C}$ or greater for several days. This is particularly needed in areas (southern Africa) where a shortage of biomass makes boiling water impractical.

Multifunetion solar greenhouses. Community size units could be used to extend growing seasons, distill drinking water, provide a central hot water heater, increase nutritional value of village diets, etc.

Renewable energy systems using linked technologies. A number of renewable energy technologies have complementary temporal or seasonal output characteristics: one delivers the desired form and amount of energy when another system is not producing use ful power. By linking units or creating units that can use energy inputs from several types of energy sources, it is possible to minimize or eliminate storage requirements. Complementary systems would also provide reliability for technologies that undergo major seasonal fluctuations; (e.g., wind energy sysems and small-scale, run-of-the-river hydroelectric systems). However, linking systems to perform one single task is not a preferred solution, since this creates an extremely expensive system that is idle most of the year. Rather, the different components must be integrated into one system that can be used for several purposes at different times of the year. One example of this approach is the work being undertaken by the Central American Institute for. Industrial Research (ICAITI), using funds provided by the InterAmerican Development Bank, to create a solar crop dryer that can be coupled with a biogas generator. This use of two energy systems solves the problem often encountered by solar crop dryers in tropical climates: The inability to perform efficiently during the rainy periods that closely follow some harvest seasons. The biogas system can be used for other tasks except when needed to assist the crop dryer (Ashworth 1979, pp. 11-13). An initial integration of two systems should be less costly and complex than two distinct systems.

\subsubsection{Applied Research/Technology Modification}

Durability under environmental stress. Considerable work is required to modify existing or proposed renewable energy systems to solve durability and performance problems caused by the harshness of the local climate. For example, blowing sand in a number of 
African sites has contributed to rapid degradation of imported photovoltaic and solar thermal systems; high humidity has proved to be a major design constraint in semitropical and island field tests; and cold temperatures require major modifications in biogas generators originally developed for operation in warm environments.

Use of local materials and construction techniques. Two major problems with imported solar technologies-their lack of durability and the lack of readily available spare partsmight be eased by increasing the use of locally manufactured components. Local villagers, artisans, and contractors have substantial experience on what materials are most durable, most resistant to erosion or local pests, and most easily produced employing standard local techniques. Using this knowledge will help alleviate maintenance problems in the future and decrease the severity of the problem of imported spare parts.

Modification of renewable energy systems to lower or eliminate maintenance. Existing designs for renewable energy systems and storage and transformation units of ten require substantial routine maintenance-lubrication, change of seals, replacement of glazing, etc. These requirements present a serious problem for remote village sites in developing countries. Applied research is needed to find low-cost solutions for reducing maintenance needs. Sealed bearings and permanent seals on pumps, for example, would lower the time lost on maintenance and partially eliminate the need for imported parts. Although durable, low-maintenance designs exist (e.g., the French SOFRETES pumps), they are very expensive because they are not mass-produced.

\subsubsection{Demonstrations of Potentially Useful Systems}

Small-scale hydroelectric or mechanical systems. The analysis in this report has indicated a wide range of potential uses for micro (less than $1 \mathrm{kWe}$ ) and small-scale (less than $100 \mathrm{kWe}$ ) hydroelectric generating systems. Designs for traditional technologies, such as water wheels, and modern water turbines are readily available. They appear to be cost-effective in many remote installations, particularly for applications where some fluctuation in output is acceptable on a daily and seasonal basis. This would minimize the need for extensive water impoundments and other major construction normally associated with larger water projects. Water-powered systems can be used for everything from irrigation pumping to cooking, although the feasibility of some applications will have to he confirmed hy engineering studies or field installations.

Biomass combustion for heat or electrical generation. In areas where there is a substantial forest products industry or biomass resource base, direct biomass combustion could be used for a variety of end-use needs, either as heat or as electricity. Although combustion of firewood, dung, and agricultural residues is the primary source of heat for cooking, water purification, and crop drying in many rural village locations, it has not been widely applied to other more commercial applications. Biomass combustion for the production of electricity and process heat is a highly developed technology in the forest products industry of many nations and could be applied easily to selected remote sites on a demonstration basis.

Cooking, water heating, and crop drying without storage. A surprising result of the matching exercises was that electricity had advantages because it is easily distributed and storage is minimal. Little is known about the impact of efficiency lossesparticularly through electric resistance heating coils and transmission lines-on the overall cost per unit of delivered energy from remote renewable energy sources. It would be use ful to install a small number of wind, photovoltaic, or hydroelectric systems for uses 
other than water-pumping, refrigeration, and lighting if there is a good match between the pattern of daily and seasonal demand and the systems output. Such systems would provide useful baseline information on the potential role of electricity in rural sites and provide cost comparisons for planners considering the extension of grid electric lines to rural villages.

\subsubsection{Commercialization Efforts}

A number of solar technologies appears to be extremely attractive for rural basic human needs right now. The problem is that the cost of an experimental system installed in $a$ remote village site is extremely high. Systems are often imported and installed by fore ign contract engineers. The delivery system for both the original components and for replacement parts is often extremely long and complex, adding cost and delay. The systems often are fabricated specially for this one application, incurring additional design and production expenses. In many cases what is needed is a simple local production capability, with initial emphas is on standardization of design, high reliability, and continuous reductions in per unit costs. Technologies that appear to be candidates for a major commercialization effort are hot water heaters, water treatment or desalination plants, small- and large-scale crop dryers, integrated wind-powered pumping systems, smallscale hydroelectric turbines, and run-of-the-river generators.

\subsection{CONCLUSIONS ON THE USEFULNESS OF THE MATCHING PROCESS}

\subsubsection{Advantages}

This report presents a process that development/energy planners can use to select the best technologies where renewable energy sources are needed. This process has several advantages and some important requirements that development organizations should consider as they establish their energy project selection procedures.

There are several advantages to employing the matching process, at least in its generalized form. The process mandates that basic human needs first be identified and then technologies chosen to meet these needs. This approach ensures that the introduction of renewable energy technologies will serve the development needs of the poorest segments of the population more directly and successfully.

The matching process also is flexible and general enough to be incorporated into a variety of different development programs. The development policy makers and planners must first determine their priorities. If the provision of energy sources is a major priority, then the planners can use the matching process to select the most appropriate renewable energy source. Since this process presents broad categories of criteria for describing and matching needs and technologies, it is applicable in a variety of situations and can be defined more specifically as on-site data is collected.

The most compelling reason to use the matching process is that it is more likely to produce a successful project, since it is more systematic and thorough. If a developing country and/or donor organization is going to invest in a renewable energy project, then they should expend enough time and resources beforehand to ensure its technological objective. 
The matching process is worthwhile because it selects technologies based on criteria that should ensure village adoption and use. These criteria are that: the technology provides the desired end product; it operates in the local environment without major maintenance and durability problems; it is not disruptive of or offensive to local social patterns and cultural tastes; and it can be integrated without excessive readjustment on the part of the villagers. The careful matching of the output of the technology to the need lowers initial capital costs for equipment and storage, making the system more economical to the user than many conventional or traditional energy devices. The use of a comprehensive set of selection criteria increases the possibility that the energy system will be adopted for long-term use, particularly when the villagers are consulted and involved in the planning and implementation of the project.

Another advantage is that it contains steps that reduce the necessity of matching all the characteristics of every technology with each need. As Sec. 2.2.3 described, a planner can measure all the technological options by the discrimination criteria of three character istics-form of output, temperature, and spatial distribution. If the technologies do not have these three characteristics, then they can be eliminated from further consideration. This avoids extensive site-specific data collection on the resource availability and social/cultural/environment effects, since these technologies do not fit the basic discrimination criteria. Energy surveys need only be geared to the technologies that do not meet the discrimination criteria; which could save resources since sitespecific data collection is the most resource-intensive part of the technology selection process.

A useful by-product of the matching process is the identification of technologies that meet certain needs criteria but must be modified to be a good match. Once identified, further research, development, and field testing of these technologies can be forwarded to research and technical institutions.

\subsubsection{Resource Considerations}

As project planners consider the advantages of employing basic need technology matching, they also should consider the institutional and financial resources required for this process. Major resources are necessary for the matching process to succeed. A commitment is needed from the development organization that the objective is to sat isfy basic energy needs and that the technology selection will be done systematically and thoroughly.

Two types of personnel are needed, especially when the development organization is first adopting, testing, and modifying the matching process. A renewable energy specialist is important for designing methods to assess the energy resource availability of a site or region and, ultimately, to define the characteristics of the technologies for the matching process. Another specialist is needed to collect data on and assess the characteristics of the basic energy needs. Since the matching process could not address all the data needed to describe each village's basic need characteristics, particularly the social/cultural/environmental ones, the specialist should be able to define what data is essential for each characterization categ ory and design an appropriate data collection system.

In addition to the personnel just described, additional staff and money are required to actually conduct the characterization survey for each project site. Although timeconsuming and labor-intensive, this survey is a vital part of the matching process and may cost less than those not conducted in the context of the matching process. Because 
this process initially screens and eliminates some technologies, the energy survey does not need to investigate the resource availability and effects of all renewable technologies for each site. Consequently, it will be less costly and time consuming.

As part of the energy/need data collection effort, the matching approach requires the involvement of local villagers in the energy data collection and matching process. Time and staff, provided by the development organization or consulting company, must be allocated to ensure that villagers are consulted about their energy needs and the introduction of a new technology. Although this consultation procedure may require additional staff at first, local villagers could be trained to collect energy data and be part of the technology selection process. This would reduce overall staff requirements and provide vital input from the villagers.

Although the matching process requires a substantial commitment of financial resources, it does not demand more than other development project planning and selection techniques that require a thorough preproject assessment of needs and traditional patterns. The comprehensive needs/technology matching is particularly essential for renewable energy projects because there is not much knowledge on what technology applications have been successful in certain developing environments. In fact, the use of the matching process could serve as a basis for assessing the field experience of particular renewable energy technologies. The characteristics of a successful matching also can be used to measure the technology's success by evaluating how well it satisfied the temporal, distributional, temperature, social, cultural and other criteria of the basic need.

In conclusion, this process can provide the best possible selection of renewable energy technologies for a need even when they have not been extensively used locally. The process identifies where $R \& D$, and field-testing are needed on technologies that meet some but not all of the energy needs criteria. The data from the matching method also can serve as a framework for assessing the introduction of the technology so that a compilation of field experience on technology applications can be collected for future use. 


\section{SECTION 5.0}

\section{REPERENCES}

Ashworth, John H. 1979. Renewable Energy Sources for the World's Poor: A Review of Current International Development Assistance Programs, SERI/TR-51-195. Golden, CO: Solar Energy Research Institute.

Burrill, George; Forman, Sylvia; Gomez, Enrique. 1980 (April). Planning Rural Energy Projects: A Rural Energy Survey and Planning Methodology. Washington, DC: Practical Concepts, Inc.

Colglazier, William E.; et al. 1978. Basic Human Needs as a Development Strategy. Consultants Working Paper for the Colombo. Plan Conference.

Donovan, Hamester, and Rattien, Inc. 1979. African Energy Survey Methodology. Vols. I and II. Washing ton, DC: Donovan, Hamester, and Rattien, Inc.

Gall, Norman. 1978. "Brazil's Alcohol Program." Common Ground. Vol. IV (No. 4): Winter; pp. 31-39.

Graham, Thomas. 1979 (Nov.). Selected Issues in Rural African Energy Assessments. Washington, DC: Donovan, Hamester, and Rattien, Inc.

Ravenholt, Albert. 1978. "Geothermal Energy in the Pacific Fire Belt." Common Ground. Vol. IV (No. 4): Winter; pp. 43-54.

Smith, Kirk R.; Santerre, Michael T.; Schlegel, Charles S. 1980 (January). Criterion Framework and Indicators for Comparing and Evaluating Alternative Energy Technologies. Honolulu, HI: Resource Systems Institute of the East-West Center. 


\section{SEP|}




\section{APPENDIX A \\ MATCHING BASIC NEEDS WITH RENEWABLE ENERGY TECHNOLOGIES}

The following matrices illustrate the matching process for four village energy needs: cooking, crop drying, food processing, and refrigeration. These represent different aspects of the energy problem. References follow the matrices.

Cooking is the major energy consumer in most rural areas and, therefore, is a top priority for energy planners. Crop drying and food processing are good examples of intermittent activities that can be coupled to a number of renewable technologies without extensive storage or energy transformation. The planner has a wide variety of options in selecting technologies to power the required tools and can link this seasonal activity with other energy demands. Refrigeration is not required in all rural locations but is very important where it is needed. It presents difficult technical problems for the creation of acceptable low-cost renewable energy systems. 


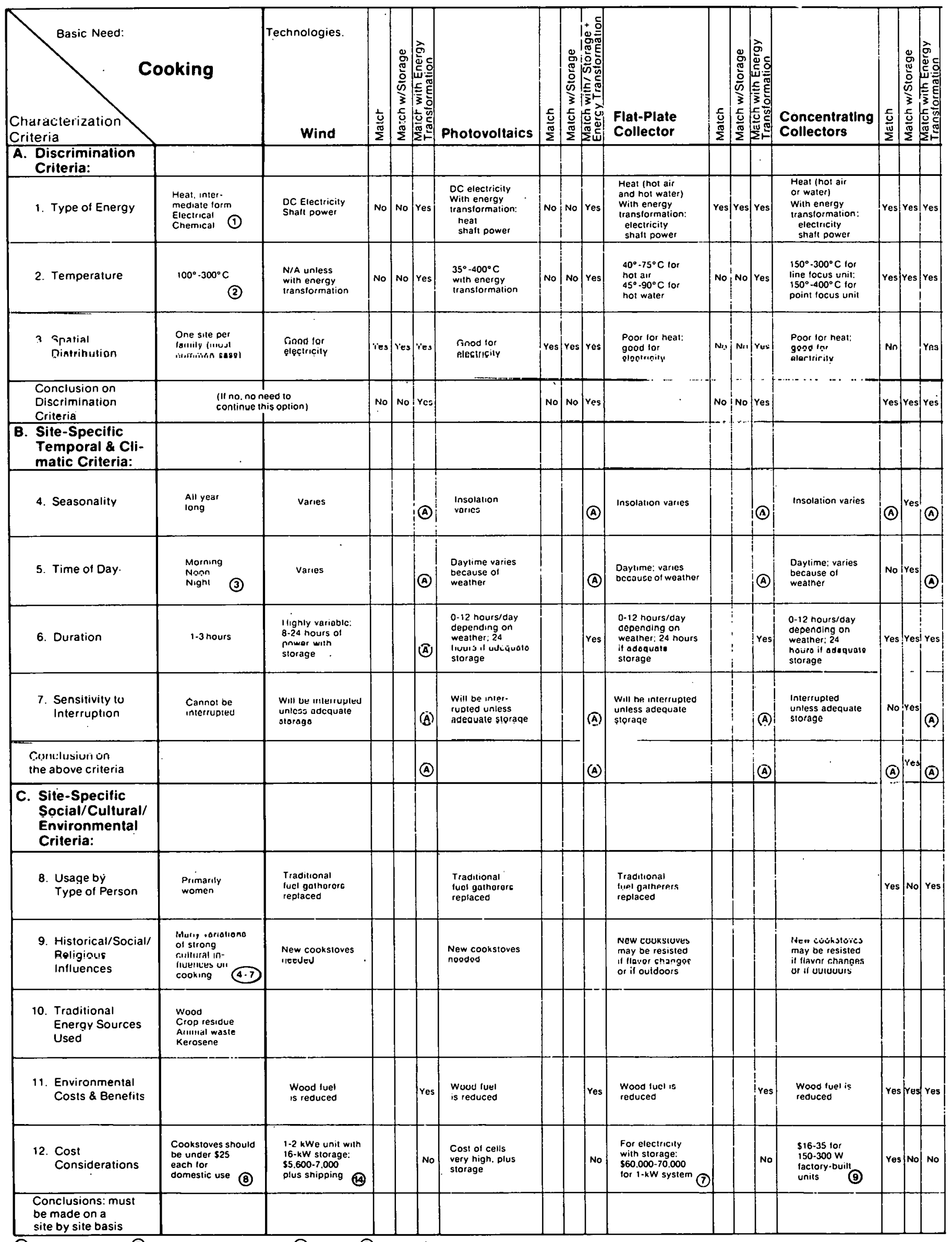

(4) It acequate resource (B) It adequate resource \& storage (C) II one site () nor needed 


\begin{tabular}{|c|c|c|c|c|c|c|c|c|c|c|c|c|}
\hline$\cdot$ & $\begin{array}{l}\text { Biogas } \\
\text { Generators } \\
\end{array}$ & \begin{tabular}{|l|} 
\\
$\frac{5}{2}$ \\
$\frac{10}{2}$ \\
\end{tabular} & 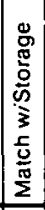 & 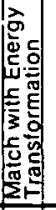 & $\begin{array}{l}\text { Biomass } \\
\text { Direct } \\
\text { Combustion } \\
\end{array}$ & \begin{tabular}{|l}
$\frac{5}{0}$ \\
$\frac{\pi}{2}$ \\
\end{tabular} & 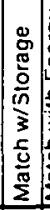 & 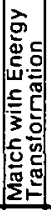 & $\begin{array}{l}\text { Small } \\
\text { Scale } \\
\text { Hydro }\end{array}$ & \begin{tabular}{|c|}
$\frac{5}{0}$ \\
$\frac{0}{2}$ \\
$\Sigma$
\end{tabular} & 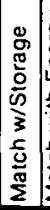 & 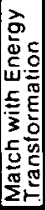 \\
\hline \multicolumn{13}{|l|}{$\begin{array}{l}\text { A. Discrimination } \\
\text { Criteria: }\end{array}$} \\
\hline 1. Type of Energy & $\begin{array}{l}\text { Heat from } \\
\text { methane gas } \\
\text { With energy } \\
\text { transformation: } \\
\text { electricity } \\
\text { shaft power } \\
\end{array}$ & Yes & N/A & No & $\begin{array}{l}\text { Heat } \\
\text { With energy } \\
\text { transformation: } \\
\text { shatt power } \\
\text { electricity } \\
\text { (steam lurbine) } \\
\end{array}$ & Yes & N/A & No & $\begin{array}{l}\text { Electricily } \\
\text { Shatt power } \\
\text { Witt energy } \\
\text { translormation: } \\
\text { neat } \\
\end{array}$ & No & No & Yes \\
\hline 2. Temperature & $100^{\circ}-400^{\circ} \mathrm{C}$ & Yes & $\mathrm{N} / \mathrm{A}$ & No & $.100^{\circ}-500^{\circ} \mathrm{C}$ & res & $N / A$ & No & $\begin{array}{l}\text { As near: } \\
100^{\circ}-400^{\circ} \mathrm{C}\end{array}$ & No & No & Yes \\
\hline $\begin{array}{l}\text { 3. Spatial } \\
\text { Distribution }\end{array}$ & $\begin{array}{l}\text { Moderate for } \\
\text { gas: good tor } \\
\text { electricity }\end{array}$ & Yes & $\mathrm{N} / \mathrm{A}$ & No & $\begin{array}{l}\text { Poor for heat: } \\
\text { good for } \\
\text { electricity }\end{array}$ & res & $|N / A|$ & No & $\begin{array}{l}\text { Poor lor } \\
\text { shatl power: } \\
\text { good lor } \\
\text { electricity }\end{array}$ & res & Yes & Yes \\
\hline $\begin{array}{l}\text { Conclusion on } \\
\text { Discrimination } \\
\text { Criteria }\end{array}$ & & Yes & N/A & No & & Yes & N/A & No & & No & No & res \\
\hline \multicolumn{13}{|l|}{$\begin{array}{l}\text { B. Site-Specific } \\
\text { Temporal \& Cli- } \\
\text { matic Criteria: }\end{array}$} \\
\hline 4. Seasonality & $\begin{array}{l}\text { Supply of waste } \\
\text { varios }\end{array}$ & Yes & & & $\begin{array}{l}\text { Supply of } \\
\text { biomass valies }\end{array}$ & yes & N/A & & $\begin{array}{l}\text { Stream flow may } \\
\text { vary. unless } \\
\text { large waler } \\
\text { storage }\end{array}$ & & & (A) \\
\hline 5. Time of Day & $\begin{array}{l}\text { Anytime when } \\
\text { waste is } \\
\text { availalle }\end{array}$ & Yes & & & Anytime & Yes & $|\mathrm{N} / \mathrm{A}|$ & & 24 hoursíday & & & (4) \\
\hline 6. Duration & $\begin{array}{l}3 \text { or more hours: } \\
24 \text { hours if } \\
\text { adequate storage }\end{array}$ & Yes & & & $\begin{array}{l}24 \text { hours it } \\
\text { input fuel is } \\
\text { availabte }\end{array}$ & Yes & [N/A & & 24 hours/day & & & (A) \\
\hline $\begin{array}{l}\text { 7. Sensitivity to } \\
\text { Interruption }\end{array}$ & $\begin{array}{l}\text { May be interrupted } \\
\text { "waste suppply } \\
\text { decreases }\end{array}$ & Yes & & & $\begin{array}{l}\text { Minimal inter. } \\
\text { ruptions it } \\
\text { adequate fuel } \\
\text { is available and } \\
\text { fed to stove }\end{array}$ & res & $\mid \mathrm{N} / \mathrm{A}$ & & $\begin{array}{l}\text { Will not be } \\
\text { interrupted it } \\
\text { stream llow is } \\
\text { constant or water } \\
\text { storage is } \\
\text { availabte }\end{array}$ & & & (A) \\
\hline $\begin{array}{l}\text { Conclusion on } \\
\text { the above criteria }\end{array}$ & & Yes & & & & Yes & & & - & & & (4) \\
\hline \multicolumn{13}{|l|}{$\begin{array}{l}\text { C. Site-Specilic } \\
\text { Social/Cultural/ } \\
\text { Environmental } \\
\text { Criteria: }\end{array}$} \\
\hline $\begin{array}{l}\text { 8. Usage by } \\
\text { Type of Person }\end{array}$ & $\begin{array}{l}\text { Requires laborers } \\
\text { 10 collect the } \\
\text { wasie fuets }\end{array}$ & & & & $\begin{array}{l}\text { Less wood } \\
\text { gathering. } \\
\text { required }\end{array}$ & Yes & $\mid \mathbf{N} / \mathbf{A}$ & & $\begin{array}{l}\text { Traditional } \\
\text { tuel gatherers } \\
\text { replaced }\end{array}$ & & & \\
\hline $\begin{array}{l}\text { 9. Historical/Social/ } \\
\text { Religious } \\
\text { Influences }\end{array}$ & $\begin{array}{l}\text { New cookstoves } \\
\text { needed }\end{array}$ & & & & $\begin{array}{l}\text { More efficient } \\
\text { cooostoves } \\
\text { required }\end{array}$ & & $N / A \mid$ & & $\begin{array}{l}\text { New cookstoves } \\
\text { required }\end{array}$ & & & \\
\hline \multicolumn{13}{|l|}{$\begin{array}{l}\text { 10. Traditional } \\
\text { Energy Sources } \\
\text { Used }\end{array}$} \\
\hline $\begin{array}{l}\text { 11. Environmental } \\
\text { Costs \& Benefits } \\
\text {. }\end{array}$ & $\begin{array}{l}\text { Less biomass } \\
\text { required plus } \\
\text { lerrilizer } \\
\text { produced: water } \\
\text { is required }\end{array}$ & Yes & & & $\begin{array}{l}\text { Less biomass } \\
\text { plus less wood } \\
\text { gaherering } \\
\text { required }\end{array}$ & & $N / A \mid$ & & $\begin{array}{l}\text { Wood luel is } \\
\text { reduced i } \\
\text { reservoir mane: } \\
\text { may use valuable } \\
\text { land }\end{array}$ & & & Yes \\
\hline $\begin{array}{l}\text { 12. Cost } \\
\text { Cinnsiderations }\end{array}$ & $\begin{array}{ll}\text { \$4.825 tor } & \text { (9) } \\
5.000 \mathrm{ft} / \mathrm{day}: & \\
\text { S10.000 lut } \\
\text { electricity }\end{array}$ & Yes & & & $\begin{array}{l}\text { Cookstoves should } \\
\text { be unners s25 int } \\
\text { domestic use } \\
\text { (8) }\end{array}$ & Yes & N/A & No & $\begin{array}{l}1 \mathrm{~kW}: \$ 4.525 \\
5 \mathrm{~kW}: \$ 8.950 \\
10 \mathrm{~kW}: \$ 13,650 \\
\text { plus electric } \\
\text { cookstoves }\end{array}$ & $\mathrm{Nn}$ & $\mathrm{No}$ & $N=$ \\
\hline $\begin{array}{l}\text { Conclusions: must } \\
\text { be made on a } \\
\text { site by site basis } \\
\end{array}$ & & & & & & & & & & & & \\
\hline
\end{tabular}




\begin{tabular}{|c|c|c|c|c|c|c|c|c|c|c|c|c|c|c|c|c|c|}
\hline $\begin{array}{l}\text { Chasic Need: } \\
\text { Criteria }\end{array}$ & $\begin{array}{l}\text { rying } \\
\text { resenvation }\end{array}$ & $\begin{array}{c}\text { Technologies. } \\
\text { Wind }\end{array}$ & $\frac{5}{0}$ & 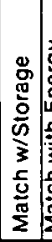 & 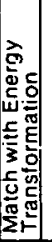 & Photovoltaics & $\mid \frac{5}{\underline{0}}$ & 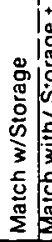 & 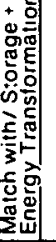 & $\begin{array}{l}\text { Flat-Plate } \\
\text { Collector }\end{array}$ & $\mid \begin{array}{l}\frac{5}{\mathrm{~g}} \\
\underline{\underline{g}} \\
\end{array}$ & 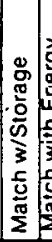 & 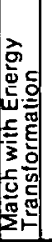 & $\begin{array}{l}\text { Concentraling } \\
\text { Collectors }\end{array}$ & \begin{tabular}{|l|}
$\frac{5}{0}$ \\
$\substack{\pi \\
\Sigma}$ \\
\end{tabular} & 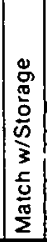 & 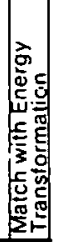 \\
\hline \multicolumn{18}{|l|}{$\begin{array}{l}\text { A. Discrimination } \\
\text { Criteria: } \\
\end{array}$} \\
\hline 1. Type of Energy & Heat & $\begin{array}{l}\text { Electricity } \\
\text { Shatt power } \\
\text { With energy } \\
\text { transtormation: } \\
\text { heat }\end{array}$ & No & No & Yes & $\begin{array}{l}\text { Electricily } \\
\text { Shaft power } \\
\text { With energy } \\
\text { transtormation: } \\
\text { neat }\end{array}$ & No & No & Yes & $\begin{array}{l}\text { Heat } \\
\text { Witn energy } \\
\text { transformation: } \\
\text { electricity } \\
\text { shatt power }\end{array}$ & Yes & Yes & (D) & $\begin{array}{l}\text { Heat } \\
\text { With energy } \\
\text { translormation: } \\
\text { eleuticity } \\
\text { shaft power }\end{array}$ & Yes & Yes & (D) \\
\hline 2. Temperature & $30^{\circ} \cdot 60^{\circ} \mathrm{C}$ & $\begin{array}{l}-35^{\circ}-400^{\circ} \mathrm{C} \\
\text { from heal }\end{array}$ & N/A & N/A & Yes & $\begin{array}{l}-35^{\circ}-400^{\circ} \mathrm{C} \\
\text { with energy } \\
\text { transtormation } \\
\text { tnto heat }\end{array}$ & N/A $\mid \mathrm{h}$ & N/A $\left.\right|^{Y}$ & Yes & $\begin{array}{l}45^{\circ}-75^{\circ} \mathrm{C} \\
\text { from nol air }\end{array}$ & Yes Y Y & Yes in & $\mathrm{N} / \mathrm{A}$ & $150^{\circ}-300^{\circ} \mathrm{C}$ & Yes & Yes & $s \mid N / A$ \\
\hline $\begin{array}{l}\text { 3. Spatial } \\
\text { Distribution }\end{array}$ & $\begin{array}{l}\text { Ocpends on tra- } \\
\text { dition: ellner } \\
\text { one site per } \\
\text { community or } \\
\text { one per famity }\end{array}$ & $\begin{array}{l}\text { Good tor } \\
\text { electricily }\end{array}$ & Yes & Yes & Yes & $\begin{array}{l}\text { Good for } \\
\text { electricity }\end{array}$ & Yes & Yes & res & $\begin{array}{l}\text { Moderate to } \\
\text { poor tor heat }\end{array}$ & resi & Yyesty & Yes & $\begin{array}{l}\text { Poor for heat: } \\
\text { good tor } \\
\text { electricity }\end{array}$ & Yes & Yes & s Yes \\
\hline $\begin{array}{l}\text { Conclusion on } \\
\text { Discrimination } \\
\text { Criteria }\end{array}$ & & & No & No & Ycs & & No & No & Yes & & Yes & Yes & (D) & & Yes & Yes & (D) \\
\hline \multicolumn{18}{|l|}{$\begin{array}{l}\text { B. Site-Specitic } \\
\text { Temporal \& Cli- } \\
\text { matic Criteria: }\end{array}$} \\
\hline 4. Seasonality & $\begin{array}{l}\text { Ourny lise harvest } \\
\text { season }\end{array}$ & Varies & & & (ब) & Insolation varies & & & (B) & Insolation varies & (a) & (A) & & Insolation varies & (a) & (a) & \\
\hline 5. Time of Day & Anytume & Varies & & & Yes? & $\begin{array}{l}\text { Daytime: varies } \\
\text { because of } \\
\text { wcather }\end{array}$ & & & & $\begin{array}{l}\text { Daytime: varies } \\
\text { because of } \\
\text { weather }\end{array}$ & Yes & Yes: & & $\begin{array}{l}\text { Daytime: varies } \\
\text { because of } \\
\text { weather }\end{array}$ & Yes & ses & \\
\hline 6. Duration & $\begin{array}{l}\text { Over } 6-12 \text { hrs/day: } \\
\text { need } 10 \text { preserve } \\
\text { heinre tond } \\
\text { spoils }\end{array}$ & $\begin{array}{l}\text { Highly yarrable } \\
8-24 \text { hours/day } \\
\text { wilh slorage }\end{array}$ & & & (B) & $\begin{array}{l}0.12 \text { hours } \\
\text { depending on } \\
\text { weather: } 24 \text { hours } \\
\text { with storage }\end{array}$ & & & (B) & $\begin{array}{l}0-12 \text { hours } \\
\text { depending on } \\
\text { weather } \\
\text { 24 hnurs with } \\
\text { storage }\end{array}$ & (A)! & Yyes & & $\begin{array}{l}0.12 \text { hours depending } \\
\text { on weather: } 24 \text { hours } \\
\text { with storage }\end{array}$ & (A) & Yes & \\
\hline $\begin{array}{l}7 \text { Sensitivity to } \\
\text { Interruption }\end{array}$ & $\begin{array}{l}\text { Can be inter- } \\
\text { ruplod for } \\
\text { short periods } \\
\text { of lime }\end{array}$ & $\begin{array}{l}\text { Will be inter- } \\
\text { rupled untess } \\
\text { adequate storage }\end{array}$ & & & ves & $\begin{array}{l}\text { Will be inter- } \\
\text { iupled inless } \\
\text { adequate slorage }\end{array}$ & & & & $\begin{array}{l}\text { Will be inier- } \\
\text { pupteo uniess } \\
\text { adeyuale siurage }\end{array}$ & roo & roo & & $\begin{array}{l}\text { Will be inter- } \\
\text { Iupted utitess } \\
\text { adequatc storage }\end{array}$ & Yoc & $=$ lroc & \\
\hline $\begin{array}{l}\text { Conclusion on } \\
\text { the above criteria }\end{array}$ & & & & & (a) & & & & (B) & & (A) & (A) & & & (A) & (A) & \\
\hline \multicolumn{18}{|l|}{$\begin{array}{l}\text { C. Site-Specific } \\
\text { Social/Cultural/ } \\
\text { Environmental } \\
\text { Eriteria: }\end{array}$} \\
\hline $\begin{array}{l}\text { 8. Usage by } \\
\text { Type ul Feısuin }\end{array}$ & $\begin{array}{l}\text { Wuitien and } \\
\text { chisdren } \\
\text { Farm families }\end{array}$ & & & & & & & & & & & & & & & & \\
\hline $\begin{array}{l}\text { 9. Historical/Social/ } \\
\text { Religious } \\
\text { Influences }\end{array}$ & $\begin{array}{l}\text { Techniques vary } \\
\text { with custom. } \\
\text { relloion. and taste } \\
\text { preterente }\end{array}$ & $\begin{array}{l}\text { Requires electric } \\
\text { device more complex } \\
\text { thon traditiona! }\end{array}$ & & & & $\begin{array}{l}\text { Electrical device } \\
\text { must be socially } \\
\text { acceplable and } \\
\text { eas' to operate }\end{array}$ & & & & $\begin{array}{l}\text { Similar to } \\
\text { traditional sun } \\
\text { truing methns }\end{array}$ & & & & $\begin{array}{l}\text { Similar to } \\
\text { iraditional sun } \\
\text { trvinn methnn }\end{array}$ & & & \\
\hline $\begin{array}{l}\text { 10. Traditional } \\
\text { Energy Sources } \\
\text { Used }\end{array}$ & $\begin{array}{l}\text { Sunlight } \\
\text { wood fuel (2) } \\
\text { burned for } \\
\text { orying'smoking }\end{array}$ & - & & & & & & & & & & & & . & & & \\
\hline $\begin{array}{l}\text { 11. Environmental } \\
\text { Costs \& Benefits }\end{array}$ & $\begin{array}{l}\text { Eomo lood cpoits } \\
\text { because drying } \\
\text { too slow } \\
\text { Wood luel } \\
\text { depleted }\end{array}$ & $\begin{array}{l}\text { Wood not needed } \\
\text { Drying occurs taster } \\
\text { with less spoilage }\end{array}$ & & & & $\begin{array}{l}\text { wood nut neeueu } \\
\text { Drying occurs } \\
\text { laster with less } \\
\text { spoilage }\end{array}$ & & & & $\begin{array}{l}\text { Wusu nul heeted } \\
\text { Drying occurs } \\
\text { laster with tess } \\
\text { spoilage }\end{array}$ & & & & $\begin{array}{l}\text { Woivd int rieoded } \\
\text { Orying occurs } \\
\text { faster with tess } \\
\text { spoilage }\end{array}$ & & & \\
\hline $\begin{array}{l}\text { 12. Cost } \\
\text { Considerations }\end{array}$ & & $\begin{array}{l}1 \mathrm{~kW} \text { with storage } \\
\$ 5.500-6.400 \\
\text { plus cost of } \\
\text { heal trans- } \\
\text { lormer }\end{array}$ & & & & $\begin{array}{l}\text { High cost of } \\
\text { photovoltaic cells } \\
\text { plus transtormer } \\
\text { and storage }\end{array}$ & & & & $\begin{array}{l}\$ 170.500 / \mathrm{m}^{\prime} \text { of } \\
\text { collector plus } \\
\text { the cost of } \\
\text { storage }\end{array}$ & & & & $\begin{array}{l}\$ 25-100 \text { for } \\
1.1 .5 \mathrm{~m} \text { manually } \\
\text { tracked units }\end{array}$ & & & \\
\hline $\begin{array}{l}\text { Conclusions: must } \\
\text { be made on a } \\
\text { site by site basis }\end{array}$ & & & & & & & & & & & & & & & & & \\
\hline
\end{tabular}

(A) It adequate resource (B) It adequate resource \& storage (C) It one site (2) nol needed 


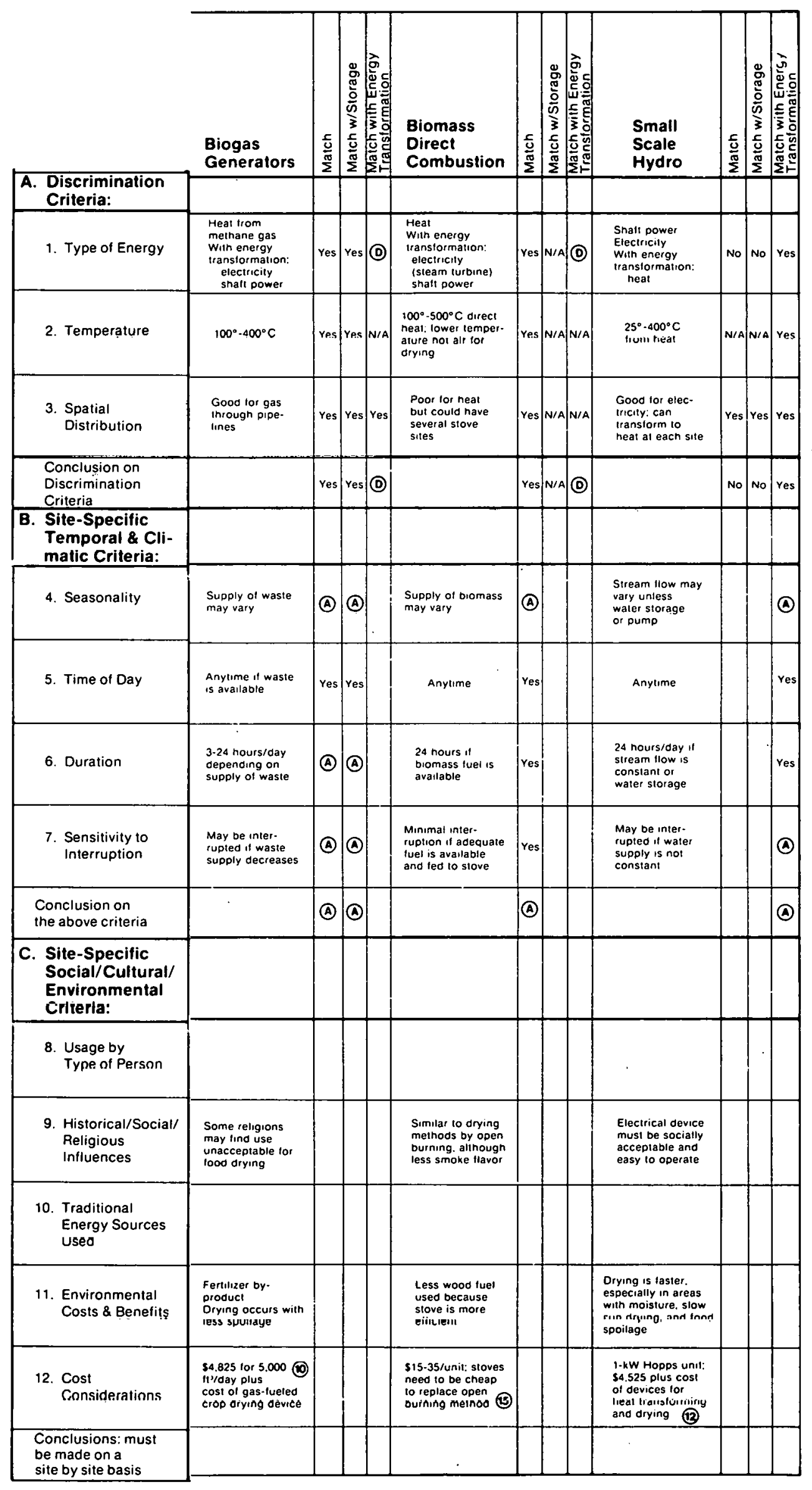




\begin{tabular}{|c|c|c|c|c|c|c|c|c|c|c|c|c|c|c|c|c|c|}
\hline $\begin{array}{l}\text { Characterization } \\
\text { Criteria }\end{array}$ & $\begin{array}{l}\text { Processing } \\
\text { ing, etc.) }\end{array}$ & $\begin{array}{r}\text { Technologies } \\
\text { Wind } \\
\end{array}$ & 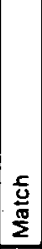 & 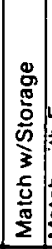 & 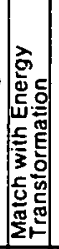 & Photovollaics & \begin{tabular}{|l|}
5 \\
\\
\\
\end{tabular} & 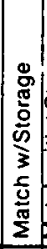 & 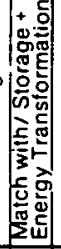 & $\begin{array}{l}\text { Flat-Plate } \\
\text { Collector }\end{array}$ & \begin{tabular}{|l|}
$\frac{5}{0}$ \\
$\frac{\pi}{2}$ \\
\end{tabular} & 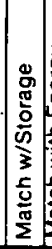 & 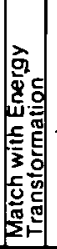 & $\begin{array}{l}\text { Concentrated } \\
\text { Collectors }\end{array}$ & $\frac{\substack{\mathrm{g} \\
\frac{\pi}{2}}}{2}$ & 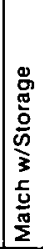 & 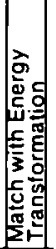 \\
\hline \multicolumn{18}{|l|}{$\begin{array}{l}\text { A. Discrimination } \\
\text { Criteria: }\end{array}$} \\
\hline 1. Type of Energy & $\begin{array}{l}\text { Mechanical } \\
\text { shatt power } \\
\text { intermediate torm: } \\
\text { electrical }\end{array}$ & $\begin{array}{l}\text { Shaft power } \\
\text { Electricity }\end{array}$ & & & (D) & $\begin{array}{l}\text { DC etectricity } \\
\text { With iranstorma- } \\
\text { lion: } \\
\text { shatt power }\end{array}$ & No & No & Yes & $\begin{array}{l}\text { Heat } \\
\text { With energy } \\
\text { transtormation: } \\
\text { shaft power } \\
\text { efectricity } \\
\end{array}$ & No & No & Yes & $\begin{array}{l}\text { Heat } \\
\text { With energy } \\
\text { translormation: } \\
\text { shatt power } \\
\text { electricity } \\
\end{array}$ & No & No & Yes \\
\hline 2. Temperature & $\begin{array}{l}\text { Not } \\
\text { Applicable }\end{array}$ & $\begin{array}{l}\text { Not } \\
\text { Applicable }\end{array}$ & N/A & N/A & $|N / A|$ & N/A & & & & $\begin{array}{l}45^{\circ}-90^{\circ} \mathrm{C} \\
\text { with he.at }\end{array}$ & N/A & N/A & $N / A$ & $150^{\circ} j^{\prime} 300^{\circ} \mathrm{C}$ & N/A & N/A & $N / A$ \\
\hline $\begin{array}{l}\text { 3. Spatial } \\
\text { Distribution }\end{array}$ & $\begin{array}{l}\text { Varies with } \\
\text { village custom: } \\
\text { at central sites or } \\
\text { each dwelling }\end{array}$ & $\begin{array}{l}\text { Poor for shalt } \\
\text { power: good for } \\
\text { electricity }\end{array}$ & (C) & (C) & Yes & $\begin{array}{l}\text { Good tor elec- } \\
\text { tricity, then } \\
\text { transtorm power } \\
\text { at each site }\end{array}$ & Yes & res & Yes & $\begin{array}{l}\text { Poor for heat } \\
\text { or shaf1 power }\end{array}$ & No & No & (C) & $\begin{array}{l}\text { Poor tor } \\
\text { neal or shat1 } \\
\text { power }\end{array}$ & No & No & (c) \\
\hline $\begin{array}{l}\text { Conclusion on } \\
\text { Discrimination } \\
\text { Ouileria }\end{array}$ & & $\dot{-}$ & (C) & (C) & (c) & . & No & No & $\gamma \in \mathrm{s}$ & ' & No & ino & (C) & & No & Nö & (C) \\
\hline \multicolumn{18}{|l|}{$\begin{array}{l}\text { B. Eite Specifio } \\
\text { Temporal \& Cli- } \\
\text { matic Criteria: }\end{array}$} \\
\hline 4. Seasonality & $\begin{array}{l}\text { After the crop } \\
\text { season }\end{array}$ & Varies & (A) & (a) & & Insntation varies & & & (B) & Insolation varies & & & (A) & Insnlation varies & & & (B) \\
\hline 5. Time of Day & Anytime & Varies & Yes & Yes & & $\begin{array}{l}\text { Daytime: varies } \\
\text { because of } \\
\text { weather }\end{array}$ & & $:$ & (B) & $\begin{array}{l}\text { Daytime; varies } \\
\text { because of } \\
\text { weather }\end{array}$ & & & Yes & $\begin{array}{l}\text { Davtime: varies } \\
\text { because of } \\
\text { weather }\end{array}$ & & & Yes \\
\hline 6. Duration & $\begin{array}{l}\text { As long as } \\
\text { needed }\end{array}$ & $\begin{array}{l}\text { Varies widely: } \\
\text { 8-24 hours with } \\
\text { storage }\end{array}$ & (A) & Yes & & $\begin{array}{l}0.12 \text { hours/day } \\
\text { depending on } \\
\text { weather and } \\
\text { season }\end{array}$ & & & (B) & $\begin{array}{l}0.12 \text { hours/day } \\
\text { dependıng on } \\
\text { weather and } \\
\text { season }\end{array}$ & & & (A) & $\begin{array}{l}0.12 \text { hours/day } \\
\text { depending on } \\
\text { weather and } \\
\text { season }\end{array}$ & & & (B) \\
\hline $\begin{array}{l}\text { 7. Sensitivity to } \\
\text { Interruption }\end{array}$ & $\begin{array}{l}\text { Can be } \\
\text { interrupled }\end{array}$ & $\begin{array}{l}\text { Will be interrupted } \\
\text { unless adequate } \\
\text { storage }\end{array}$ & Yes & Yes & & $\begin{array}{l}\text { Will be interrupted } \\
\text { unless adequate } \\
\text { storage }\end{array}$ & $!$ & & Yes & will be interrupted & & & Yes & $\begin{array}{l}\text { Will be interrupted } \\
\text { unless adequate } \\
\text { storage }\end{array}$ & & & Yes: \\
\hline $\begin{array}{l}\text { Oinclusion on } \\
\text { the above criterla }\end{array}$ & & & (A) & (a) & & & & & (B) & & & & (A) & & & & (B) \\
\hline \multicolumn{18}{|l|}{$\begin{array}{l}\text { O. Gite-Epceific } \\
\text { Social/Cultural/. } \\
\text { Environmental } \\
\text { Criteria: }\end{array}$} \\
\hline $\begin{array}{l}\text { 8. Usage by } \\
\text { Type of Person }\end{array}$ & $\begin{array}{l}\begin{array}{l}\text { Primarily } \\
\text { woman and } \\
\text { children }\end{array} \\
\text { (d)(j) }\end{array}$ & $\begin{array}{l}\text { Labor may be } \\
\text { replaced }\end{array}$ & & & & $\begin{array}{l}\text { Labor may be } \\
\text { replaced }\end{array}$ & & & & ; $\begin{array}{l}\text { Labor may be } \\
\text { replaced }\end{array}$ & & & & $\begin{array}{l}\text { Labor may be } \\
\text { replaced }\end{array}$ & & & \\
\hline $\begin{array}{l}\text { 9. Historical/Social/ } \\
\text { Religious } \\
\text { Influences }\end{array}$ & $\begin{array}{l}\text { Religious and } \\
\text { cultural patterns } \\
\text { may atfeci how } \\
\text { tood is processed }\end{array}$ & $\begin{array}{l}\text { New processing } \\
\text { device must be } \\
\text { accepted and } \\
\text { leasible to } \\
\text { operate }\end{array}$ & & & & $\begin{array}{l}\text { New processing } \\
\text { device musi be } \\
\text { accepted and } \\
\text { feasible to } \\
\text { operale }\end{array}$ & & & 1 & $\begin{array}{l}\text { New processing } \\
\text { device must be } \\
\text { accepted and } \\
\text { leasible to operate }\end{array}$ & & & & $\begin{array}{l}\text { New processing } \\
\text { device must be } \\
\text { accepted and } \\
\text { feasible to operate }\end{array}$ & & & \\
\hline $\begin{array}{l}\text { 10. Trartitinnal } \\
\text { Energy Sources } \\
\text { Used }\end{array}$ & $\begin{array}{l}\text { Miunth puwt: } \\
\text { Animal power }\end{array}$ & & & & & & & & & & & & & & & & \\
\hline \multicolumn{18}{|l|}{$\begin{array}{l}\text { 11. Environmental } \\
\text { Costs \& Benefits }\end{array}$} \\
\hline $\begin{array}{l}\text { 12. Cost } \\
\text { Considerations }\end{array}$ & & $\begin{array}{l}\text { Sailwing windmill } \\
\text { ano grinaer: } \\
\$ 350-500 \\
1-2 \mathrm{kWe} \text { wind } \\
\text { lurbine with } \\
16-\mathrm{kW} \text { storage } \\
\$ 5.600-7.000\end{array}$ & Yes & Yes & & $\begin{array}{l}1.8-\mathrm{kW} \text { system } \\
\$ 50.400 \text { plus } \\
\text { milt hammer }\end{array}$ & & & No & $\begin{array}{l}\$ 170-500 / m^{\prime} \\
\text { collector with } \\
\text { grinder and } \\
\text { storage }\end{array}$ & & & No & $\begin{array}{l}17 \mathrm{~m}^{\prime} \text { system } \\
\text { with } 1 \text { hour } \\
\text { slorage: } \\
\text { \$4.000 }\end{array}$ & & & No \\
\hline $\begin{array}{l}\text { Conclusions: must } \\
\text { be made on a } \\
\text { site by site basis }\end{array}$ & & & & & & & & & & & & & & & & & \\
\hline
\end{tabular}

(a) If adequate resource () If adequate resource \& slorage (C) II one stie (D) noi needed 


\begin{tabular}{|c|c|c|c|c|c|c|c|c|c|c|c|c|}
\hline . & $\begin{array}{l}\text { Biogas } \\
\text { Generators }\end{array}$ & \begin{tabular}{|l}
$\frac{5}{\mathrm{~g}}$ \\
$\frac{\mathrm{o}}{\mathrm{w}}$ \\
\end{tabular} & 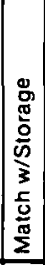 & 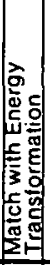 & $\begin{array}{l}\text { Biomass } \\
\text { Direct } \\
\text { Combustion } \\
\end{array}$ & $\begin{array}{l}\frac{5}{5} \\
\frac{\pi}{2} \\
\end{array}$ & 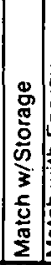 & 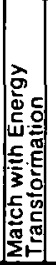 & $\begin{array}{l}\text { Small } \\
\text { Scale } \\
\text { Hydro }\end{array}$ & $\begin{array}{l}\frac{5}{\mathrm{y}} \\
\frac{\mathrm{w}}{\mathrm{T}} \\
\end{array}$ &  & 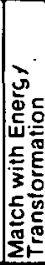 \\
\hline \multicolumn{13}{|l|}{$\begin{array}{l}\text { A. Discrimination } \\
\text { Criteria: }\end{array}$} \\
\hline 1. Type of Energy & $\begin{array}{l}\text { Heat from methane } \\
\text { gas } \\
\text { With energy } \\
\text { ranstormation: } \\
\text { shatt power } \\
\text { electricity } \\
\end{array}$ & No & No. & |res & $\begin{array}{l}\text { Heat } \\
\text { With energy } \\
\text { transtormation: } \\
\text { shaft power } \\
\text { electricity } \\
\text { (steam turbine) } \\
\end{array}$ & No & No & Yes & $\begin{array}{l}\text { Electricity } \\
\text { Shaft power } \\
\text { With energy } \\
\text { transforgation: } \\
\text { heal } \\
\end{array}$ & res & res & (D) \\
\hline 2. Temperature & $N / A$ & & & & N/A & & & & N/A & & & \\
\hline $\begin{array}{l}\text { 3. Spatial } \\
\text { Distribution }\end{array}$ & $\begin{array}{l}\text { Guud fur gas: } \\
\text { poor for shatt power }\end{array}$ & Yes & Yes & res & $\begin{array}{l}\text { Poor for heal } \\
\text { or shatt power }\end{array}$ & No & No & (C) & $\begin{array}{l}\text { Poor for shat1 } \\
\text { power: good for } \\
\text { electricity }\end{array}$ & (C) & Yes & Yes \\
\hline $\begin{array}{l}\text { Conclusion on } \\
\text { Discrimination } \\
\text { Criteria }\end{array}$ & & No & No & Yes & & No & No & (C) & & (c) & Yes & (D) \\
\hline \multicolumn{13}{|l|}{$\begin{array}{l}\text { B. Site-Specific } \\
\text { Temporal \& Cli- } \\
\text { malic Criteria: } \\
\end{array}$} \\
\hline 4. Seasonality & $\begin{array}{l}\text { Supply of waste } \\
\text { may vary }\end{array}$ & & & (A) & $\begin{array}{l}\text { Supply of biomass } \\
\text { may vary }\end{array}$ & & & (A) & $\begin{array}{l}\text { Stream llow may } \\
\text { vary without } \\
\text { water storage } \\
\text { or pump }\end{array}$ & (৫) & (৯) & \\
\hline 5. Time of Day & $\begin{array}{l}\text { Anytime is } \\
\text { waste is } \\
\text { available }\end{array}$ & & & res & Anytime, & & & ress & Anytime & res & res & \\
\hline 6. Duration & $\begin{array}{l}24 \text { hours/day if } \\
\text { waste supply } \\
\text { conslant }\end{array}$ & & & (A) & $\begin{array}{l}\text { Anytime if biomass } \\
\text { luet is constant }\end{array}$ & & & (A) & $\begin{array}{l}24 \text { nours/day it } \\
\text { stream tlow is } \\
\text { constant or } \\
\text { water storage } \\
\text { available }\end{array}$ & (A) & Yes & \\
\hline $\begin{array}{l}\text { 7. Sensitivity to } \\
\text { Interruption }\end{array}$ & $\begin{array}{l}\text { May be inter- } \\
\text { rupted it waste } \\
\text { supply decreases }\end{array}$ & & & Yes & $\begin{array}{l}\text { Minimal inter- } \\
\text { ruption it } \\
\text { adequate fuel } \\
\text { is available; } \\
\text { and lea to } \\
\text { stove }\end{array}$ & & & Yes & $\begin{array}{l}\text { Will not be } \\
\text { interrupted it } \\
\text { stream llow is } \\
\text { constant or } \\
\text { water storage } \\
\text { available }\end{array}$ & Yes & Yes & \\
\hline $\begin{array}{l}\text { Conclusion on } \\
\text { the above criteria }\end{array}$ & & & & (ब) & $\vdots$ & & & (A) & & (A) & (ब) & \\
\hline \multicolumn{13}{|l|}{$\begin{array}{l}\text { C. Site-Specific } \\
\text { Social/Cultural/ } \\
\text { Environmental } \\
\text { Criteria: }\end{array}$} \\
\hline $\begin{array}{l}\text { 8. Usage by } \\
\text { Type of Person }\end{array}$ & $\begin{array}{l}\text { Labor tor pro- } \\
\text { cessing replaced: } \\
\text { labor tor luel } \\
\text { collection needed }\end{array}$ & & & & $\begin{array}{l}\text { Labor lor } \\
\text { processing ré- } \\
\text { placed: labor for } \\
\text { fuel collection } \\
\text { needed }\end{array}$ & & & & $\begin{array}{l}\text { Labor tor } \\
\text { processing } \\
\text { replaced }\end{array}$ & & & \\
\hline $\begin{array}{l}\text { 9. Historical/Social/ } \\
\text { Religious } \\
\text { Influences }\end{array}$ & $\begin{array}{l}\text { New processing } \\
\text { method must be } \\
\text { acceptable and } \\
\text { leasible to } \\
\text { operate }\end{array}$ & & & & $\begin{array}{l}\text { New processing } \\
\text { method must be } \\
\text { acceptable and } \\
\text { teasible to operate }\end{array}$ & & & & $\begin{array}{l}\text { New processing } \\
\text { method must be } \\
\text { acceptabte and } \\
\text { leasible to operate }\end{array}$ & & & \\
\hline \multicolumn{13}{|l|}{$\begin{array}{l}\text { 10. Traditional } \\
\text { Energy Sources } \\
\text { Used }\end{array}$} \\
\hline $\begin{array}{l}\text { 11. Environmental } \\
\text { Costs \& Benefits }\end{array}$ & $\begin{array}{l}\text { Fertilizer } \\
\text { by-product }\end{array}$ & & & & $\begin{array}{l}\text { Wood fuel } \\
\text { required }\end{array}$ & & & & $\begin{array}{l}\text { Possibte tand } \\
\text { lost to reservoir }\end{array}$ & & & \\
\hline $\begin{array}{l}\text { 12. Cost } \\
\text { Considerations }\end{array}$ & $\begin{array}{l}\$ 10.000 \text { for } 3.00011 / 3 \\
\text { day of gas } \\
\text { with engine tor } \\
\text { shaft power }\end{array}$ & & & Yeses & $\begin{array}{l}\text { Cost of boiler and } \\
\text { turbine to oroduce } \\
\text { ohalt power }\end{array}$ & & & Yres & $\begin{array}{l}1 \mathrm{~kW}: \$ 4.525 \\
2 \mathrm{~kW}: \$ 8.950 \\
\text { plus grinining } \\
\text { equipment }\end{array}$ & & Yes & \\
\hline $\begin{array}{l}\text { Conclusions: must } \\
\text { be made on a } \\
\text { site by site basis }\end{array}$ & & & & & & & & & & & & \\
\hline
\end{tabular}




\begin{tabular}{|c|c|c|c|c|c|c|c|c|c|c|c|c|c|c|c|c|c|}
\hline $\begin{array}{l}\text { Chasic Need: } \\
\text { Criteria }\end{array}$ & geration & $\begin{array}{c}\text { Technologies. } \\
\text { Wind }\end{array}$ & $\frac{5}{\mathrm{~g}}$ & 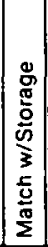 & 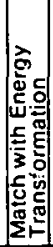 & Pholovoltaics & $\frac{5}{\underline{\underline{T}}}$ & 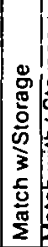 & 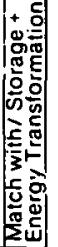 & $\begin{array}{l}\text { Flat-Plate } \\
\text { Collector }\end{array}$ & \begin{tabular}{|l|}
$\frac{5}{y}$ \\
$\frac{\pi}{2}$ \\
\end{tabular} & 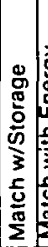 & 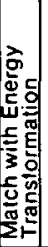 & $\begin{array}{l}\text { Concentrating } \\
\text { Collectors }\end{array}$ & $\left|\begin{array}{l}\frac{5}{0} \\
\frac{0}{20} \\
\frac{\pi}{2}\end{array}\right|$ & 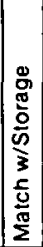 & 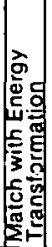 \\
\hline \multicolumn{18}{|l|}{$\begin{array}{l}\text { A. Discrimination } \\
\text { Criteria: }\end{array}$} \\
\hline 1. Type of Energy & $\begin{array}{l}\text { Electricity } \\
\text { Heat } \\
\end{array}$ & $\begin{array}{l}\text { Eleciricity } \\
\text { Shaft power } \\
\text { With energy } \\
\text { transformation: } \\
\text { heat } \\
\end{array}$ & Yes & Yes & Yes & $\begin{array}{l}\text { Electricity } \\
\text { With energy } \\
\text { Iransformation: } \\
\text { neat }\end{array}$ & Yes & Yes & Yes & $\begin{array}{l}\text { Heat (not water } \\
\text { or air) } \\
\text { With energy } \\
\text { transformation: } \\
\text { electricity } \\
\text { shaft power } \\
\end{array}$ & Yes & Yes & Yes & $\begin{array}{l}\text { Heat } \\
\text { With energy } \\
\text { transformation: } \\
\text { electricity } \\
\text { shall power }\end{array}$ & Yes & Yes & Yes \\
\hline 2. Temperature & $\begin{array}{l}\text { Cooling: } \\
0^{\circ}-10^{\circ} \mathrm{C}: \\
\text { Heat: } \\
100^{\circ}-300^{\circ} \mathrm{C}\end{array}$ & $\begin{array}{l}35^{\circ}-400^{\circ} \mathrm{C} \\
\text { with encrgy } \\
\text { transiormation }\end{array}$ & N/A & $N / A$ & Yes & $\begin{array}{l}-35^{\circ}-400^{\circ} \mathrm{C} \\
\text { with energy } \\
\text { transformation }\end{array}$ & N/A & N/A & Yes & $\begin{array}{l}\text { Heat: } \\
85^{\circ}-90^{\circ} \mathrm{C}\end{array}$ & No & No & N/A & $\begin{array}{l}\text { Heat: } \\
150^{\circ}-300^{\circ} \mathrm{C}\end{array}$ & Yes & Yos & Yes \\
\hline $\begin{array}{l}\text { 3. Spatial } \\
\text { Distribution }\end{array}$ & $\begin{array}{l}1.50 \text { locations } \\
\text { per viltage: } \\
\text { one central site } \\
\text { likely }\end{array}$ & $\begin{array}{l}\text { Good tor } \\
\text { electricity }\end{array}$ & Yes & Yes & Yes & $\begin{array}{l}\text { Good tor electricity: } \\
\text { Door for heat }\end{array}$ & Yes & Yes & (C) & $\begin{array}{l}\text { Poor lor heat: } \\
\text { good for electricity }\end{array}$ & (C) & (c) & Yes & $\begin{array}{l}\text { Poor for heat: } \\
\text { good for electricity }\end{array}$ & (C) & (C) & Yes \\
\hline $\begin{array}{l}\text { Conclusion on } \\
\text { Discrimination } \\
\text { Criteria }\end{array}$ & & & Yes & Yes & Yes & & Yes & Yes & $\mathfrak{B}$ & & Nn & $\mathrm{Nn}$ & Yas & & Yes & Ves & vini. \\
\hline \multicolumn{18}{|l|}{$\begin{array}{l}\text { B. Slte-Specific } \\
\text { Temporal \& Cli- } \\
\text { matic Criteria: }\end{array}$} \\
\hline 4. Seasonality & $\begin{array}{l}\text { All year } \\
\text { long }\end{array}$ & Varies & No & (A) & No & Insolation varies & No & (A) & & Insolation varies & & & (B) & \multirow{2}{*}{$\begin{array}{l}\text { Insolation varies } \\
\text { Daytime: bul varies } \\
\text { because ol weather }\end{array}$} & No & (B) & (B) \\
\hline 5. Time of Day & 24 nours/day & Varies & No & (A) & No & $\begin{array}{l}\text { Daytime: but varies } \\
\text { because of weather }\end{array}$ & No & (A) & & $\begin{array}{l}\text { Daytime: but varies } \\
\text { because of weather }\end{array}$ & & & (B) & & No & (B) & (B) \\
\hline 6. Duration & 24 nours/day & $\begin{array}{l}\text { Highly variable: } \\
\text { 8-24 hours of } \\
\text { power with } \\
\text {.adequate storage }\end{array}$ & No & (A) & No & $\begin{array}{l}0.12 \text { hours/tay } \\
\text { but varies with } \\
\text { weather: } \\
24 \text { hours/day with } \\
\text { adequate storage }\end{array}$ & No & (a) & & $\begin{array}{l}0-12 \text { hours/day. } \\
\text { but varies with } \\
\text { weather: } 24 \\
\text { hours/day with } \\
\text { adequate storage }\end{array}$ & & & (B) & $\begin{array}{l}0-12 \text { hours/day. } \\
\text { but varies with } \\
\text { weather: } 24 \\
\text { hours/day with } \\
\text { adequate storage }\end{array}$ & No & (B) & (B) \\
\hline $\begin{array}{l}\text { 1. Sensitivity to } \\
\text { Interruption }\end{array}$ & $\begin{array}{l}\text { Cannot be } \\
\text { interrupted }\end{array}$ & $\begin{array}{l}\text { Will te interrupted } \\
\text { unless adequate } \\
\text { slorage }\end{array}$ & No & (A) & No & $\begin{array}{l}\text { Will be interrupled } \\
\text { unless adequate } \\
\text { Gtoragc }\end{array}$ & No & (A) & & $\begin{array}{l}\text { Will be interrupted } \\
\text { unless adequate } \\
\text { storagc }\end{array}$ & & & (B) & $\begin{array}{l}\text { Will be interrupted } \\
\text { unless adequate } \\
\text { sturage }\end{array}$ & No & (B) & (B) \\
\hline $\begin{array}{l}\text { Conclusion on } \\
\text { the ahnug criteria }\end{array}$ & & & No & (A) & No & & No & (A) & & & & & (a) & & No & (B) & (B) \\
\hline \multicolumn{18}{|l|}{$\begin{array}{l}\text { C. Site-Specific } \\
\text { Social/Cultural/ } \\
\text { Environmental } \\
\text { Criteria: }\end{array}$} \\
\hline $\begin{array}{l}\text { 8. Usage by } \\
\text { Type of Person }\end{array}$ & $\begin{array}{l}\text { Medieal stall: } \\
\text { Persons who need } \\
\text { food storage }\end{array}$ & & & & & & & & & & & & & & & & \\
\hline \multicolumn{18}{|l|}{$\begin{array}{l}\text { 9. Historical/Social/ } \\
\text { Religious } \\
\text { Influences }\end{array}$} \\
\hline $\begin{array}{l}10 \text { Tinililiuninl } \\
\text { Energy Sources } \\
\text { Used }\end{array}$ & $\begin{array}{l}\text { None. } 1000 \\
\text {. drying used }\end{array}$ & & & & & & & & & & & & & & & & \\
\hline $\begin{array}{l}\text { 11. Environmental } \\
\text { Costs \& Benefits }\end{array}$ & $\begin{array}{l}\text { Improved nealth } \\
\text { Can preserve } \\
\text { perishable crops }\end{array}$ & & & & & & & & & & & & & & & & \\
\hline $\begin{array}{l}\text { 12. Cost } \\
\text { Considerations }\end{array}$ & & $\begin{array}{l}\text { 1-2-kW unit with } \\
16-\mathrm{kW} \text { storage: } \\
\$ 5.600-7.100\end{array}$ & & & & $\begin{array}{l}1-\mathrm{kW} \text { system } \\
\text { with storage and } \\
\text { OC refrigerator: } \\
\$ 32.000\end{array}$ & No & No & No & $\begin{array}{l}3-\mathrm{kW} \text { refrigerator } \\
\text { with 100+m? } \\
\text { collector: } \\
\$ 12.800\end{array}$ & & & No & $\begin{array}{l}\text { 3-kW system } \\
\text { with heat storage } \\
\text { and absorption } \\
\text { refrigerator: } \\
\$ 14.800\end{array}$ & & & No \\
\hline $\begin{array}{l}\text { Conclusions: must } \\
\text { be made on a } \\
\text { site by site basis }\end{array}$ & & & & & & & & & & & & & & ' & & & \\
\hline
\end{tabular}




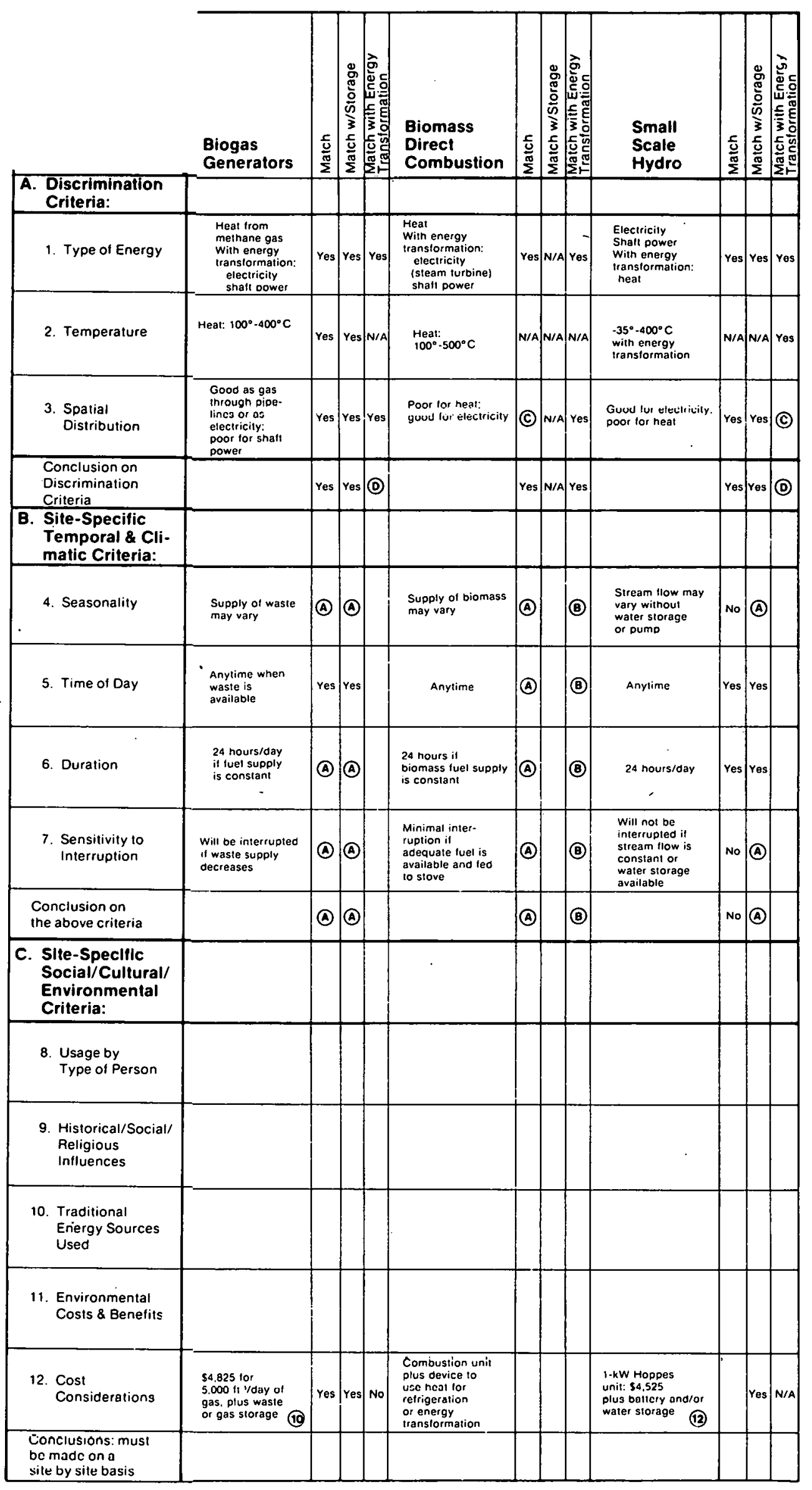


SERP 


\section{APPENDIX A: REFERENCES}

1. Energy Technical Support Unit, AERE Harwell. Renewable Energy Sources for Developing Countries-An Initial Appraisal. Oxfordshire, England: September 1978.

2. Floor, W. M. The Energy Sector of the Sahelian Countries. The Hague, Netherlands: Policy Planning Section; Ministry of Foreign Affairs; April 1977.

3. McLoughlin, Peter F. M. African Food Production Systems: Case and Theory. Baltimore, MD: Johns Hopkins University Press; 1970.

4. Hammond, Peter B. Yatenga: Technology in the Culture of a West African Kingdom. New York, NY: Free Press; 1966.

5. French, David. Renewable Energy for Africa: Needs, Opportunities, Issues. Report \#AF R-147-46. Washington, DC: U.S. Agency for International Development; 14 July 1978.

6. Cecelski, Elizabeth; Dunkerly, Joy; Ramsey, William. Household Energy and the Poor in the Third World. Research Paper R-15. Washington, DC: Resources for the Future; July 1979.

7. Langerhorst, J; Prast, G; Thalhammer, T. Solar Energy: A Report on the Difficulties Involved in Applying Solar Energy in Developing Countries. Eindhoven, Netherlands: The Philips Research Laboratories; 11 February 1977.

8. Makhijani, Arjun. "Solar Energy and Rural Development for the Third World." Bulletin of Atomic Scientists. June 1976.

9. Walton, J. D.; Roy, A. H.; Bomar, S. H. A State-of-the-Art Survey of SolarPowered Irrigation Pumps, Solar Cookers, and Wood Burning Stoves for Use in SubSahara Africa. Atlanta, GA: Georgia Institute of Technology; January 1980.

10. Reddy, A. K. "The Trojan Horse." CERES. March-April 1976.

11. Allison, Southerland, and Gordan. 1976.

12. U.S. National Academy of Sciences. Energy for Rural Development. Washington, DC: National Academy of Sciences; 1976.

13. Gross, S. P.; Gross, W. W. "Harnessing the Andean Sun." Sun World. Vol. 3 (No. 3): p. 65 .

14. Price List. BEST Energy Systems; Necedah, WI.

15. Morgan, Robert; Icerman, Larry. Appropriate Technology for Renewable Resource Utilization. St. Louis, Mo: Washington University Center for Development Technology; June 1979.

16. Frankel, Peter. Food from Windmills. London, England: Intermediate Technology Development Group; November $19^{\prime} / 5$.

17. Bifano, William J.; Ratajczak, Anthony F.; Martz, James E. A Photovoltaic Power System in the Remote African Village of Tangaye, Upper Volta. Technical Memorandum 79318. Cleveland, OH: NASA Lewis Research Center; November 1979. 
SERI 


\section{APPENDIX B}

\section{CURRENT RESEARCH ON NEEDS AND TECHNOLOGIES}

In the last five years the impact of energy prices and availability on the economic and social development of rural areas of Third World nations has become a concern throughout the development community. Reports have been directed primarily at producing needed information for project design or for the testing and modification of new experimental energy technologies. For analytic purposes, these studies can be divided into five categories. Each study has contributed to an increased understanding of the problem of rural energy needs. How this understanding can be incorporated in to the matching process is described in this report.

\section{B-1. BASEINE DATA COLLECTION: CURRENT ENERGY CONSUMPTION AND RESOURCE AVAILABILITY}

These studies focus on two fundamental questions: how is energy being used today by consumers in developing countries, and what energy. resources are available to meet current consumption needs or to substitute for energy sources with high costs or unacceptable environmental and social side effects? They normally report case-study information for one location [1-3], one country [4-11], a single geographical region [13-15], or comparative groups of developing countries [16-19]. In some cases, a complete energy flow analysis is provided that includes approximating the energy content of human and animal labor by using the caloric content of the food as well as the relative efficiencies of converting food into work [16, 20, 21]. Some studies have attempted a systematic assessment of available energy resources that provide the additional energy required to accelerate development activities [17, 22] .

This literature has provided guidance for this study. First, the literature has established the importance of nonfossil fuels in the life of the rural and urban poor. The major emphasis has been on the role of firewood, but there also has been discussion of the use of dung, peat, and agricultural residues as fuel. Second, the major energy consuming tasks have been identified in the rural sector and assigned rough weights for the energy inputs of each basic need. Third, anecdotal information has been provided on the impacts of $r$ ising consumption of noncommercial energy on the rural environment and on the lives of the rural villagers. Fourth, several studies have examined the low efficiency of current energy conversion devices-particularly traditional cookstoves-and have indicated how efficient, low-cost systems could greatly lower the environmental stress from energy resource consumption. Last, case studies have shown what the site-specific energy needs are, and how the temporal, spatial, and thermal characteristics of energy needs can vary drastically from site to site even within a small region.

These studies have clearly shown the need for new energy sources to meet a small number of basic human needs. They also have demonstrated that the energy choice must be tailored to each site and need. However, they have not provided a selection process for meeting primary energy needs or what technologies to use.

\section{B-2. ENERGY FOR BASIC NEEDS}

These publications closely ally with the preceding studies. Rather than cataloguing existing energy use patterns, they discuss what basic development objectives could be 
met if additional increments of energy were made available [14, 16, 22-24]. Often the focus is on one or two basic needs, such as water pumping, cooking, grinding of crops, potable water. Some reports estimate the amount of energy needed to reach a certain level of output that currently is not met due to a lack of affordable energy or extreme poverty or is provided by human or animal labor.

\section{B-3. TECHNOLOGY PERFORMANCE REPORTS}

Other literature discusses the performance and problems of experimental renewable energy systems installed in laboratory settings [25-30] or in developing country locations as part of a development project [31-38]. In most cases, the emphasis is on the ability of the system or its individual components to perform with high efficiency rather than to meet a clearly outlined set of development objectives. Nonetheless, these documents characterize the technology options as well as estimate costs of field installations.

\section{B-4. COMPILATIONS OF RENEWABLE ENERGY TECHNOLOGY OPTIONS}

Several recent reports, of ten commissioned by foreign assistance organizations, provide an extensive catalogue of system types available to developing countries. Some deal with conventional and nonconventional energy technologies [39-40], some attempt to include cost estimates as well as system characteristics [41-45], while others provide an extensive description of technologies available for end-use needs [42, 46, 47]. Most catalogues do excellent jobs of providing information on the size and nature of each system's energy output, but little information on how that output couples with the different enduse energy needs or with different social, cultural, and economic systems.

\section{B-5. AGGREGATE STUDIES OF FUTURE PATTERNS OF ENERGY DEMAND AND SUPPLY FOR DEVELOPING COUNTRIES}

Within the last five years, there have been a large number of sophisticated computer projections of energy supply requirements of developing countries for the next 5 to 25 years. In some cases, the developing countries are taken as a residual, which balances the projected energy demand and the supplies of conventional fuels available [48]. In other models, developing countries collectively are seen as direct competitors with developed countries for limited supplies of conventional fuels [49-50]. Several computer simulations also have been run that focus directly on the developing countries, aggregating the projected demand by country, region, or level of per capita income.

These reports are not particularly helpful for the development of the technology selection process. 'They are important, however, since they indicate the global energy shortage that affects the decision making of donor institutions. Also, they show just how important rapid development and deployment of new energy sources in developing countries are for meeting basic human needs and for alleviating pressures on global fuel supplies.

The authors have been dependent on the reported results of energy consumption patterns as well as the scanty information on the performance of installed renewable energy systems in developing countries. Data often is localized and region-specific. For example, information on energy needs and resources in Africa and South Asia have been relatively easy to locate, while little information has been collected or disseminated on rural 
energy usage patterns in Latin America, the Caribbean Islands, Southeast Asia, and the Middle East. Several excellent compendia have been relied on for technology performance data. In particular, Walton et al. [46] are extremely useful for information on solar-powered irrigation systems and wood stoves, while Morgan and Icerman [42] provide a thorough and clear analysis of the different operating characteristics of a range of wind energy conversion systems and wood stoves. These broad analyses have been double-checked, where possible, against the reported performance of individual systems installed and monitored in developing countries. 


\section{SERY}




\section{APPENDIX B: REFERENCES}

1. Tarrant, James J. "Energy Needs and Tasks in Debarek, Ethiopia." An Appendix to Energy for the Villages of Africa. Authored by James Howe et al. Washington, DC: Overseas Development Council; 25 February 1977; pp. 54-73.

2. Holtzman, John S. "Energy Needs and Tasks in a Sahelian Village." An Appendix to Energy for the Villages of Africa. Authored by James Howe et al. Washing ton, DC: Overseas Development Council; 25 February 1977; pp. 74-89.

3. Lawand, T. A.; et. al: Rural Energy Centre for Africa Using Solar, Wind, and Biogas Energies. Quebec, Canada: Brace Research Institute; 1977.

4. Brown, Norman L; Howe, James W. "Solar Energy for Village Development." Science. Vol. 199: 10 February 1978; pp. $651-657$.

5. Tewari, Sharat K. "Wind Energy Conversion in India." Renewable Energy Resources and Rural Applications in the Developing World. Edited by Norman L. Brown. Boulder, CO: Westview Press; 1978.

6. Powell, John W. "Wood Waste as an Energy Source in Ghana." Renewable Energy Resources and Applications in the Developing World. Edited by Norman L. Brown. Boulder, CO: Westview Press; 1978.

7. Ebinger, Charles; Page, Helena. "Energy and Economic Development in Pakistan." Common Ground. Vol. IV (No. 4): Winter 1978; pp. 11-16.

8. Henderson, P. D. India: The Energy Sector. Washington, DC: The World Bank; 1975.

9. Pachauri, R. K. Energy and Economic Development in India. New York: Praeger Special Studies in International Economics and Development; 1977.

10. U.S. Department of Energy. Joint Egypt/United States Report on Egypt/United States Cooperative Energy Assessment, Vol. 1-5. Washington, DC: U.S. Government Printing Office; February 1979.

11. Sen, Lalit K. "Rural Energy Scene in India." Productivity. Vol. XIX (No. 4): January-March 1979; pp. 655-683.

12. Floor, W. M. The Energy Sector of the Sahelian Countries. The Hague, Netherlands: Ministry of Foreign Affairs; April 1977.

13. Donovan, Hamester, and Rattien, Inc. Caribbean Region Cooperation Study. Washing ton, DC: Donovan, Hamester, and Rattien, Inc.; 6 January 1979.

14. Howe, James; et al., Energy for the Villages of Africa. Washington, DC: Overseas Development Council; 1977.

15. Strout,.A. M. "Energy and Economic Growth in Central America." 2nd Annual Review of Energy. 1977; pp. 291-305.

16. Makhijani, Arjun; Poole, Alan. Energy and Agriculture in the Third World. Cambridge, MA: Ballinger Press; $19 \overline{75 .}$

17. Palmedo, Philip F.; Nathans, Robert; Beardsworth, Edward; Hale, Samuel Jr. Energy Needs, Uses, and Resources in Developing Countries. Long Island, NY: Brookhaven National Laboratory, National Center for the Analysis of Energy Systems; March 1978. 
18. Cecelski, Elizabeth; Dunkerley, Joy; Ramsey, William. Household Energy and the Poor in the Third World. Research Paper \#R-15. Washington, DC: Resources for the Future; 1979.

19. Fernandez, Judith. Household Energy Use in Non-OPEC Developing Countries. Working Draft. Santa Monica, CA: The Rand Corporation; April 1979.

20. Revelle, Roger. "Energy Use in Rural India." Science. Vol. 192: 4 June 1976; pp. 969-975.

21. Singh, G.; Chancellor, W. "Energy Inputs and Agricultural Production Under Various Regimes of Mechanization in Northern India." American Journal of Agricultural Economics. Vol. 18 (No. 2).

22. Harper, Jerome; Smith, Wayne; Marlani, Eliseo. An Assessment of Peruvian Biomass Resources and Alternatives. Argonne, IL: Argonne National Laboratory; Oetober 1978.

23. Reddy, Amulya K. N. "Energy Options for the Third World." Bulletin of the A tomic Scient ists. May 1978; pp. 28-33.

24. Revelle, Roger. "Requirements for Energy in the Rural Areas of Developing Countries." Renewable Resources and Rural Applications in Developing World. Edited by Norman Brown. Boulder, CO: Westview Press; 1978.

25. Matlin, Ron W. Design Optimization and Performance Characteristics of a Photovoltaic Microirrigation System for Use in Developing Countries. Report COO/4094-33. Lexing ton, MA: MIT Lincoln Laboratory; July 1979.

26. Moustafa, S. M. A.; Brusewitz, G. H. "Direct Use of Solar Energy for Water Desalination." Solar Energy. Vol. 22 (No. 2): 1979; pp. 141-148.

27. Kettani, M. Ali. "Review of Solar Desalination." Sunworld. Vol. 3 (No. 3): 1979; pp. 76-85.

28. Development Technology Centre of the Asian Institute of Technology. "A Simple Solar Dryer." Appropriate Technology. Vol. 5 (No. 2): August 1978; p. 7.

29. Von Oppen, M. "An Automatic Tracking Device for the Sun Basket." Appropriate Technology. Vol. 5 (No. 2): August 1978; p. 7.

30. Ramakumar, R. "Harnessing Wind Power in Developing Countries." Presented at the Intersociety Energy Conversion Engineering Conference; Newark, DE; August 1975. Newark, DE: IECE.

31. Board on Science and Technology for International Development. Methane Generation from Human, Animal, and Agricultural Wastes. Washing ton, DC: National Academy of Sciences; 1977.

32. Prasad, C. R.; Prasad, K. K.; Reddy, A. K. N. "Bio-Gas Plants: Prospects, Problems and Tasks." Economic and Political Weekly. Vol. IX: August 1974; pp. 1347-1364.

33. Smith, Douglas V.; Allison, Stephen. Micro-Irrigation with Photovoltaics. Working Paper. Cambridge, MA: Massachusetts Institute of Technology Energy Laboratory; February 1977.

34. Stambolis, C. Solar Water Heating in the Sudan: A Preliminary Investigation. London: Heliotechnic Associates International; February 1979. 
35. Polgar, S. "Technical Note: Use of Solar Generators in Africa for Broadcasting Equipment." Solar Energy. Vol 19 (No. 2): pp. 201-204.

36. Bifano, William J.; Ratajczak, Anthony F.; Martz, James E. "A Photovoltaic Power System in the Remote African Village of Tangaye, Upper Volta." Technical Memorandum 79318. Cleveland, OH: NASA Lew is Research Center; November 1979 .

37. "French Solar-Powered Irrigation Pump Installed in Mexico." Solar Energy Digest. Vol. 6 (No. 2): February 1976; pp. 1-5.

38. Little, E. C. S. "The Mini-Cusab Kiln for Rapid Small-Scale Manufacture of Charcoal from Scrub, Cocoanut Wood and Cocoanut Shells." Appropriate Technology. Vol 5 (No. 1): May 1978; p. 12.

39. Fallen-Bailey, D. G.; Byers, T. A. Energy Options and Policy Issues in Developing Countries. Working Paper No. 350. Washington, DC: World Bank Staff; August 1979.

40. Cirillo, Richard R.; Baldwin, Thomas E. Characterization of Energy Technologies for Use in Less Developed Countries. Argonne, IL: Argonne National Laboratory; January 1978.

41. Langerhost, J.; Prast, G.; Thalhammer, T. Solar Energy: Report on a Study of the Difficulties Involved in Applying Solar Energy in Developing Countries. Eindhoven, Netherlands: Philips Research Laboratories; 11 February 1977.

42. Morgan, Robert P.; Icerman, Larry J. Appropriate Technology for Renewable Resource Utilization. St. Louis, MO: Washington University Center for Development Technology; June 1979.

43. Board on Science and Technology for International Development. Energy for Rural Development: Renewable Resources and Alternative Technologies for Developing Countries. Washington, DC: National Academy of Sciences; 1976.

44. U.N. Economic and Social Commission for Asia and the Pacific. Proceedings of the Meeting of the Expert Working Group on the Use of Solar and Wind Energy. New York, NY: United Nations; 1976.

45. Eggers-Lura, A. Solar Energy in Developing Countries. Oxford, England: Pergamon Press; $197 \bar{\theta}$.

46. Walton, J. D., Jr., Roy, A. H.; Bomar, S. H., Jr. A State of the Art Survey of Solar Powered Irrigation Pumps, Solar Cookers, and Wood Burning Stoves. Altanta, GA: Georgia Institute of Technology, Engineering Experiment Station; January 1978.

47. Brace Research Institute. A Survey of Solar Agricultural Dryers. Technical Report T99. Quebec: Brace Research Institute; December 1975.

48. Lambertini, Andrian. Energy and Petroleum in Non-OPEC Developing Countries, 1974-1980. Washing ton, DC: The World Bank; February 1976.

49. Workshop on Alternative Energy Strategies. Energy: Global Prospects: Global Prospects 1985-2000. New York, NY: McGraw-Hill Book Company; 1977.

50. World Energy Conference. World Energy Resources, 1985-2020. Guildford, England: IPC Science and Technology Press; 1978. 


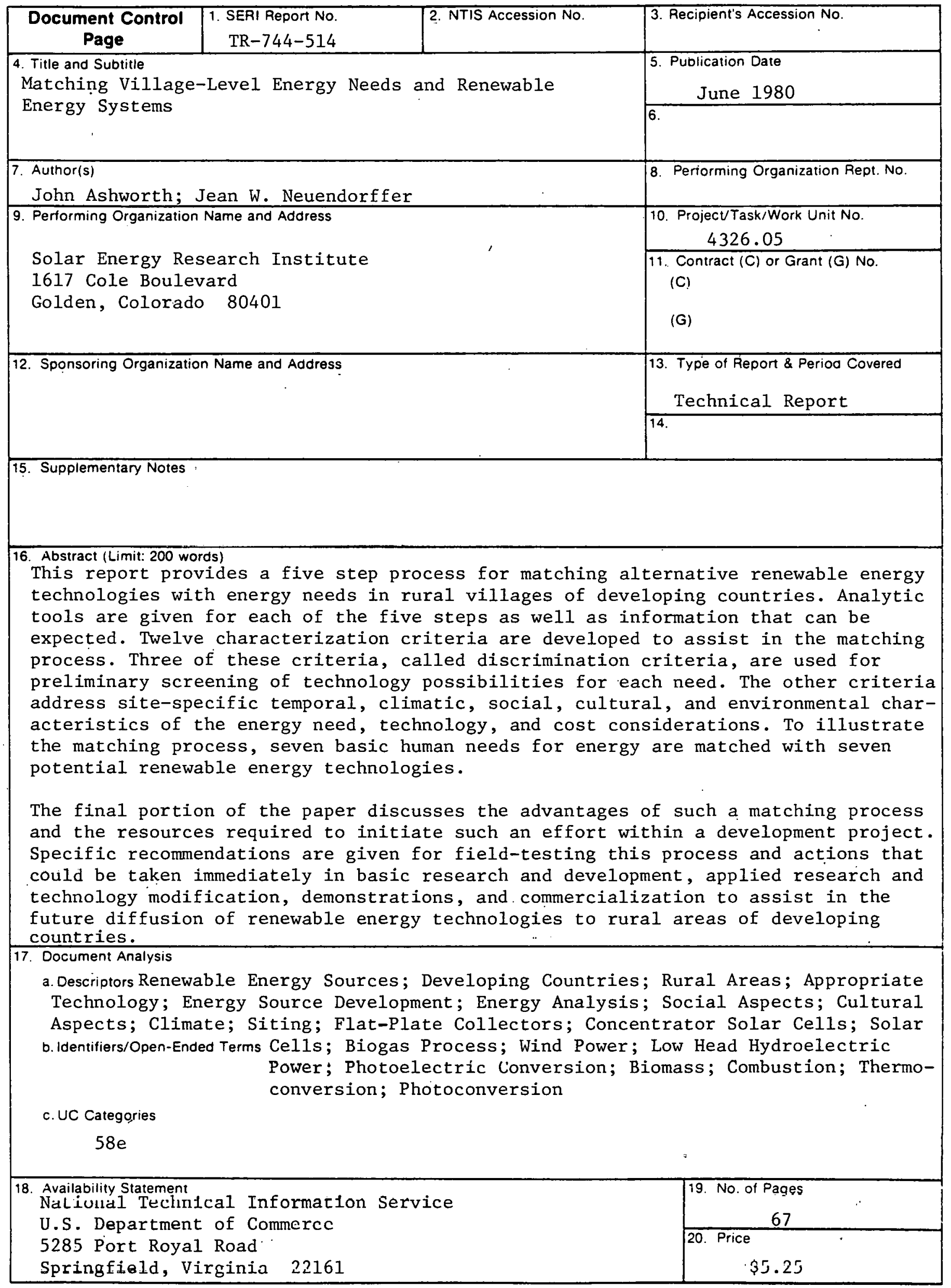

